\title{
Interaction of Isocitrate Lyase with Proteins Involved in the Energetic Metabolism in Paracoccidioides lutzii
}

\author{
Kleber Santiago Freitas e Silva ${ }^{1, *}$, , Raisa Melo Lima ${ }^{1}{ }^{(0)}$, Patrícia de Sousa Lima ${ }^{1}{ }^{(}$, \\ Lilian Cristiane Baeza ${ }^{1,2}$, Roosevelt Alves da Silva ${ }^{3}\left(\mathbb{D}\right.$, Célia Maria de Almeida Soares ${ }^{1}(\mathbb{D}$ and \\ Maristela Pereira ${ }^{1, *}$ \\ 1 Laboratório de Biologia Molecular, Instituto de Ciências Biológicas, Universidade Federal de Goiás, \\ Goiânia 74690-900, Goiás, Brazil; raisamelolima@hotmail.com (R.M.L.); pathricialima@gmail.com (P.d.S.L.); \\ lilianbaeza@gmail.com (L.C.B.); cmasoares@gmail.com (C.M.d.A.S.) \\ 2 Laboratório de Microbiologia Experimental, Centro de Ciências Médicas e Farmacêuticas, \\ Universidade Estadual do Oeste do Paraná, Cascavel 85819-170, Paraná, Brazil \\ 3 Núcleo Colaborativo de Biossistemas, Instituto de Ciências Exatas, Universidade Federal de Jataí, \\ Jataí 75801-615, Goiás, Brazil; rooseveltfisicaufg@gmail.com \\ * Correspondence: sammy@ufg.br (K.S.F.eS.); mani@ufg.br (M.P.); Tel./Fax: +55-62-35211110 (M.P.)
}

Received: 24 September 2020; Accepted: 20 November 2020; Published: 23 November 2020

\begin{abstract}
Background: Systemic mycosis is a cause of death of immunocompromised subjects. The treatment directed to evade fungal pathogens shows severe limitations, such as time of drug exposure and side effects. The paracoccidioidomycosis (PCM) treatment depends on the severity of the infection and may last from months to years. Methods: To analyze the main interactions of Paracoccidioides lutzii isocitrate lyase (ICL) regarding the energetic metabolism through affinity chromatography, we performed blue native PAGE and co-immunoprecipitation to identify ICL interactions. We also performed in silico analysis by homology, docking, hot-spot prediction and contact preference analysis to identify the conformation of ICL complexes. Results: ICL interacted with 18 proteins in mycelium, 19 in mycelium-to-yeast transition, and 70 in yeast cells. Thirty complexes were predicted through docking and contact preference analysis. ICL has seven main regions of interaction with protein partners. Conclusions: ICL seems to interfere with energetic metabolism of P. lutzii, regulating aerobic and anaerobic metabolism as it interacts with proteins from glycolysis, gluconeogenesis, TCA and methylcitrate cycles, mainly through seven hot-spot residues.
\end{abstract}

Keywords: protein-protein interaction; Paracoccidioides; central metabolism; isocitrate lyase

\section{Introduction}

The genus Paracoccidioides comprises an intricate group of five phylogenetic species: Paracoccidioides brasiliensis, Paracoccidioides lutzii, Paracoccidioides americana, Paracoccidioides venezuelensis and Paracoccidioides restrepiensis [1,2]. They are the causative agents of paracoccidioidomycosis (PCM), which is a neglected human systemic mycosis. Paracoccidioides is thermodimorphic, the yeast form produces multi-budding cells at $37^{\circ} \mathrm{C}$ and the mycelium infecting form grows at $22{ }^{\circ} \mathrm{C}[3]$.

The inhalation of fungal propagules is the first step of the infection that takes place in the lungs, where the parasite turns into its pathogenic yeast-like form [4]. The transition from mycelium to yeast form also takes place in vitro after a temperature shift. The thermodimorphism is governed by a set of molecular changes which have been investigated through transcriptomic and proteomic approaches [5,6]. Macrophages in the alveolar tissue is the first defense mechanism fought by the 
pathogen. Infection success depends on Paracoccidioides' ability to evade oxidative stress generated by the harsh environment inside macrophages [7].

Systemic mycosis is an important cause of morbidity and mortality, especially against immunocompromised subjects [8]. The treatment directed to evade fungal pathogens shows severe limitations, such as time of drug exposure and side effects [9]. The PCM treatment depends on the severity of the infection and may last from two months, in simple cases, to even years in more complex cases. Therefore, there is a real necessity of finding new potential antifungal drugs. Several natural compounds have been tested against Paracoccidioides and they have shown promising results [10-13].

Enzymes from the glyoxylate cycle are related to virulence in a large variety of pathogens [14] and inhibitors have been tested against them, such as Candida albicans $[15,16]$, Mycobacterium tuberculosis $[17,18]$ and P. lutzii [11]. The ICL enzyme is expressed in organisms of several kingdoms, bacteria and fungi [19], protozoa [20], algae [21] and plants [22]. Developing inhibitors against the specific enzymes from the glyoxylate cycle is very promising since malate synthase (MLS) and isocitrate lyase (ICL) are not found in humans. Therefore, a possible drug based on their structures would be less toxic to human cells. ICL is a metabolic enzyme important to microorganisms' growth based on fatty acids, which is fed by anaplerotic reactions from the glyoxylate shunt. The enzyme is also related to the metabolism of propionyl CoA produced by $\beta$-oxidation. In addition, deletion of the ICL gene prevets microorganisms to incorporate carbon from fatty acids [23].

Research on molecular biology and related fields has shed light on the understanding of molecular mechanisms related to protein function. Yet, proteins usually exert their functions at cellular levels through interactions with other proteins or molecules [24]. For the investigation of protein-protein interactions (PPIs), its biological context needs to be taken into account. A specific, transient interaction occurs depending on the cell state, protein modification processes, cell phase, presence of a cofactor or the environment where the cells are [25]. Identified proteins by PPI methodologies are normally isolated from the soluble extract, which contains proteins from different cellular compartments. We did not find any studies related to sub-cellular compartments where ICL is expressed in Paracoccidioides. For future perspectives, the identification of the sub-cellular compartments where ICL is present could help to validate more interactions of this enzyme. Regarding model organisms, ICL is present in the extracellular matrix [26], vacuoles [27] and cytoplasm [28,29].

Here, we analyzed the main PPIs stablished by ICL in three different $P$. lutzii phases, mycelium, mycelium-to-yeast transition and yeast regarding the energetic metabolism. The PPIs experiments were performed by affinity chromatography, blue native PAGE (BN-PAGE) and validated by co-immunoprecipitation. In addition, we conducted in silico approaches in order to analyze the interface of interaction between ICL and target proteins. ICL has seven main conserved points of interaction with the 15 selected proteins. The residue 505 is the region with the most preferable area of interaction. Thus, ICL may interfere with the central energetic metabolism of $P$. lutzii that could regulate aerobic and anaerobic metabolism, as it interacts with proteins from glycolysis, gluconeogenesis, tricarboxylic acid cycle (TCA) and methylcitrate cycles, mainly through seven hot-spot residues.

\section{Materials and Methods}

\subsection{P. lutzii Growth Conditions}

The P. lutzii (ATCC-MYA-826) isolate was used to perform all of the experiments described here. The fungus was maintained on Fava-Netto solid medium $(1.0 \% w / v$ peptone, $0.5 \%$ w $/ v$ yeast extract, $0.3 \% w / v$ proteose peptone, $0.5 \% w / v$ beef extract, $0.5 \% w / v \mathrm{NaCl}, 4 \% w / v$ glucose, and $1.4 \% w / v$ agar, $\mathrm{pH}$ 7.2) [30]. Mycelium cells grew at $22^{\circ} \mathrm{C}$ and were collected on the 12 th day of growth. Yeast cells grew at $37^{\circ} \mathrm{C}$ and they were collected on the 3rd day of growth. To perform protein extraction, mycelium cells were grown in Fava-Netto liquid medium for $72 \mathrm{~h}$ at $22^{\circ} \mathrm{C}$ and then mycelium-to-yeast transition was induced by temperature shift from $22^{\circ} \mathrm{C}$ to $37^{\circ} \mathrm{C}$ [4]. The growth was tracked through 
a Neubauer chamber and cells were retrieved four days after the temperature shift was established in order to perform protein extraction.

\subsection{Preparation of P. lutzii Protein Extracts}

The protein extraction was methodologically performed equally for mycelium, mycelium-to-yeast transition and yeast cells. P. lutzii cells were retrieved by centrifugation at $10,000 \times g$ for $15 \mathrm{~min}$ at $4{ }^{\circ} \mathrm{C}$ and washed in sterile phosphate buffered saline (PBS; $1.4 \mathrm{mM} \mathrm{KH} \mathrm{PO}_{4}, 8 \mathrm{mM} \mathrm{Na}_{2} \mathrm{HPO}_{4}, 140 \mathrm{mM}$ $\mathrm{NaCl}, 2.5 \mathrm{mM} \mathrm{KCl}$ at pH 7.2). The cells were resuspended in $20 \mathrm{mM}$ Tris- $\mathrm{HCl}$ at $\mathrm{pH} 8.8$ and $2 \mathrm{mM}$ $\mathrm{CaCl}_{2}$. Protease inhibitor was added to avoid protein degradation (GE Healthcare, Uppsala County, Uppsala, Sweden). The samples were subjected to cell disruption through five cycles of $30 \mathrm{~s}$ each, using a bead beater equipment (BioSpec, Bartlesville, OK, USA). Samples were centrifuged at 10,000 $\mathrm{g}$ for $15 \mathrm{~min}$ at $4{ }^{\circ} \mathrm{C}$ and the supernatant was collected to determine protein concentration through the Bradford (Sigma Aldrich, St. Louis, MI, USA) method.

\subsection{P. lutzii Recombinant ICL Expression and Purification}

The plasmid bearing the cDNA encoding ICL was obtained from [31] and transformed into Escherichia coli BL21 C43 (DE3) cells. ICL expression was induced with $1 \mathrm{mM}$ of isopropyl thio-b-D-galactoside (IPTG; Sigma Aldrich, St. Louis, MI, USA). Cells were collected by centrifugation at $10,000 \times g$ for $15 \mathrm{~min}$ at $4{ }^{\circ} \mathrm{C}$. The cells were resuspended in $20 \mathrm{mM}$ Tris- $\mathrm{HCl}$ at $\mathrm{pH} 8.8$ and $2 \mathrm{mM}$ $\mathrm{CaCl}_{2}$, then incubated with lysozyme and eventually lysed by sonication. The sample was centrifuged at $10,000 \times g$ for $15 \mathrm{~min}$ at $4{ }^{\circ} \mathrm{C}$. The supernatant with the soluble protein fraction was retrieved and applied to a nickel-nitrilotriacetic acid resin (Ni-NTA; Invitrogen, Carlsbad, CA, USA). For $1 \mathrm{~mL}$ of lysate, $250 \mu \mathrm{L}$ of resin were used. The soluble protein fraction was incubated with the resin for $2 \mathrm{~h}$. Next, the resin was washed five times with native wash buffer $\left(50 \mathrm{mM} \mathrm{Na}_{2} \mathrm{HPO}_{4}, 20 \mathrm{mM}\right.$ imidazol, $\mathrm{pH}$ 8.0) to clean non-specific interactions. The recombinant ICL bound to the resin was eluted with salty buffer ( $50 \mathrm{mM} \mathrm{Na}_{2} \mathrm{HPO}_{4}, 250 \mathrm{mM}$ imidazol, $\mathrm{pH}$ 6.0) and ICL concentration was measured by the Bradford protocol [32].

\subsection{Protein Co-Precipitation}

Recombinant ICL was used as a bait protein for the chromatographic approach. In the first step, recombinant ICL was immobilized into the Ni-NTA resin. Next, soluble fraction of the protein extracts from mycelium, mycelium-to-yeast transition and yeast was incubated in the Ni-NTA system with ICL for $2 \mathrm{~h}$. The bait-and-prey systems were washed and eluted in order to undergo tryptic digestion. The control was prepared with the incubation of $P$. lutzii protein extract with Ni-NTA resin. Proteins identified in both systems (Ni-NTA + ICL + protein extract and Ni-NTA + protein extract) were excluded from the results.

\subsection{Blue Native PAGE}

BN-PAGE assay was performed according to a protocol stablished previously [33] with some modifications. Soluble total protein extracts from mycelium, mycelium-to-yeast transition and yeast were used in the experiments. The samples were dissolved in $10 \%(w / v)$ glycerol and $50 \mathrm{mM}$ Bis-Tris/HCl at $\mathrm{pH}$ 7.0. A 5-18\% $(w / v)$ polyacrylamide gradient gel was casted and a gel buffer $(150 \mathrm{mM}$ Bis-Tris/HCl, $1.5 \mathrm{M}$ aminocaproic acid at $\mathrm{pH} 7.0$ ), a cathode buffer (50 mM tricine, $15 \mathrm{mM}$ Bis-Tris/HCl, $0.02 \%$ Coomassie blue G-250, at $\mathrm{pH} 7.0$ ) and an anode buffer (50 mM Bis-Tris/ $\mathrm{HCl}$ at $\mathrm{pH} 7.0$ ) were used to conduct the native electrophoresis. The procedure was performed on a vertical Hoefer SE600 ruby apparatus (GE Healthcare) at $15{ }^{\circ} \mathrm{C}$, with a starting voltage of $150 \mathrm{~V}$ until the loaded samples were inside the stacking gel, then a constant current limited to $15 \mathrm{~mA}$ and a voltage of $300 \mathrm{~V}$ were applied. 


\subsection{Sample Digestion, $L C-H D M S^{E}$ Analysis and Data Acquisition}

The pull down eluted from each sample was submitted to concentration and subsequently washed with $50 \mathrm{mM}$ ammonium bicarbonate through a $10-\mathrm{kDa}$ molecular weight cut off in an ultracel-regenerated membrane (Amicon Ultra centrifugal filter, Millipore, Bedford, MA, USA). Protein concentrations were determined via Bradford assay. Equimolar amounts of proteins from each sample $(150 \mu \mathrm{g})$ were digested and prepared for nanoESI-HDMS ${ }^{\mathrm{E}}$ (Nano Electrospray High-Definition Mass Spectrometry) analysis and acquisition, as previously described [34], with some modifications. Qualitative and quantitative 2D nanoUPLC coupled to nanoESI-HDMS ${ }^{\mathrm{E}}$ experiments were conducted using $60 \mathrm{~min}$ reversed-phase (RP) acetonitrile $(0.1 \% v / v$ formic acid) gradients $(7-40 \%(v / v)$ at $500 \mathrm{~nL} / \mathrm{min}$ on a nanoACQUITY UPLC 2D RP $\times$ RP Technology system. A RP XBridge BEH130 C18300 $\mu \mathrm{m} \times 50 \mathrm{~mm}$, $5 \mu \mathrm{m}$ nanoflow column ( $\mathrm{pH}$ 10, first-dimension online fractioning) was used in conjunction with a nanoACQUITY UPLC High-Strength Silica (HSS) T3 $75 \mu \mathrm{m} \times 15 \mathrm{~cm}, 1.8 \mu \mathrm{m}$ column $(\mathrm{pH} 3$, second-dimension analytical runs). Typical on-column sample loads were approximated at $5 \mathrm{mg}$ total protein, containing $150 \mathrm{fmol} / \mu \mathrm{L}$ of an exogenous internal standard digest (rabbit Glycogen Phosphorylase B, accession P00489). For all measurements, the mass spectrometer was operated in resolution mode (20,000 resolution FWHM). All analyses were performed using nanoelectrospray ionization in the positive ion mode nanoESI $(+)$ and a nanoLockSpray (Waters) ionization source.

The mass spectrometer was calibrated with a fragment ion spectrum (MS/MS) of the [Glu1]-fibrinopeptide B (Glu-Fib) doubly charged precursor at $m / z 785.8426$ using a $250 \mathrm{fmol} / \mu \mathrm{L}$ solution delivered through the reference sprayer of the NanoLockSpray source at $0.5 \mu \mathrm{L} / \mathrm{min}$. This precursor was also used for Lockmass correction channel, which was sampled every $30 \mathrm{~s}$. Multiplexed data-independent acquisitions (DIA) with specificity and selectivity of nonlinear "T-wave" ion mobility $\left(\mathrm{HDMS}^{\mathrm{E}}\right.$ ) experiments were performed using a Synapt G2-S HDMS mass spectrometer (Waters), set to switch automatically between low ( $3 \mathrm{eV}$ ) and high-energy (19-45 eV) HDMS Scans (HDMS ${ }^{\mathrm{E}}$ ), applied to the transfer "T-wave" collision-induced dissociation cell filled with argon gas. The quadrupole (MS profile) was adjusted so that the nanoUPLC-HDMS ${ }^{\mathrm{E}}$ data were effectively acquired from an $m / z$ range of 400-2000, which ensured that any masses observed in the high-energy spectra of less than $\mathrm{m} / \mathrm{z} 400$ arose from dissociations in the collision cell.

\subsection{Data Processing}

Mass spectrometry data obtained from nanoESI-HDMS ${ }^{\mathrm{E}}$ were processed and searched against the Paracoccidioides Pb01 database (http://www.broadinstitute.org/annotation/genome/paracoccidioides_ brasiliensis/Multiome.html) using ProteinLynx Global Server (PLGS) version 3.0.2 (Waters, Manchester, UK). Protein identification and quantitative data packaging were performed using dedicated algorithms [35,36]. MS spectra were collected in centroid, de-isotoped and charge-state-reduced mode to obtain associated product ions and a monoisotopic mass for all peptides. Protein identification criteria included: (i) minimum number of fragments ion matches per peptide (2), (ii) minimum number of fragments ion matches per protein (5), (iii) minimum number of peptide matches per protein (1), (iv) maximum protein mass $(600 \mathrm{kDa})$, (v) trypsin was chosen as the primary digest reagent, (vi) carbamidomethylation of cysteine residues as a fixed modification, (vii) methionine oxidation and phosphoryl STY as a variable modification (viii) and a maximum $4 \%$ false-positive discovery rate, in at least two out of three technical replicate injections. The cut-off of protein in the identification is according to the number of peptides identified after crossing the results of the identification with the genome of the organism, which is available on Uniprot. The score values are listed in Table 1. The PDBs of the relevant structures that interact with ICL and their significance (C-score confidence and TM-score) used for decoys were added in Supplementary Table S1. 
Table 1. Proteins related to central metabolism binding to ICL in the pull-down assay in P. lutzii mycelium, mycelium-to-yeast transition and yeast forms.

\begin{tabular}{|c|c|c|}
\hline Accession & Protein Name & Score $* *$ \\
\hline & Mycelium & \\
\hline & Glycolysis and Gluconeogenesis & $60,211.38$ \\
\hline PAAG_01995 & fructose-bisphosphate aldolase & $11,197.06$ \\
\hline PAAG_02585 & triosephosphate isomerase * & $29,783.99$ \\
\hline PAAG_02869 & phosphoglycerate kinase & $37,493.65$ \\
\hline PAAG_06380 & pyruvate kinase & $24,097.65$ \\
\hline \multirow[t]{2}{*}{ PAAG_08203 } & phosphoenolpyruvate carboxykinase & $10,288.74$ \\
\hline & Tricarboxylic-acid pathway & $18,022.91$ \\
\hline PAAG_01534 & $\begin{array}{l}\text { pyruvate dehydrogenase E1 component } \\
\text { subunit beta }\end{array}$ & $54,603.02$ \\
\hline PAAG_03330 & dihydrolipoyl dehydrogenase & $18,252.14$ \\
\hline PAAG_00417 & succinyl-CoA ligase subunit alpha & $15,495.53$ \\
\hline PAAG_01463 & succinyl-CoA ligase subunit beta & $45,050.75$ \\
\hline PAAG_07729 & isocitrate dehydrogenase subunit 2 & $29,021.65$ \\
\hline PAAG_00053 & malate dehydrogenase & $64,147.15$ \\
\hline PAAG_08449 & malate dehydrogenase & $40,336.05$ \\
\hline \multirow[t]{2}{*}{ PAAG_05048 } & 3-isopropylmalate dehydratase large subunit & $24,897.33$ \\
\hline & Electron transport & $16,888.22$ \\
\hline \multirow[t]{2}{*}{ PAAG_04820 } & ATPase alpha subunit & $17,866.72$ \\
\hline & Respiration & $82,884.62$ \\
\hline PAAG_06796 & cytochrome c oxidase subunit $5 b$ & $60,211.38$ \\
\hline \multirow[t]{2}{*}{ PAAG_08037 } & ATP synthase subunit beta & $11,197.06$ \\
\hline & Pentose-phosphate pathway & $29,783.99$ \\
\hline PAAG_04166 & transaldolase & $37,493.65$ \\
\hline \multirow[t]{3}{*}{ PAAG_04444 } & transketolase & $24,097.65$ \\
\hline & Mycelium-to-yeast transition & \\
\hline & Glycolysis and Gluconeogenesis & \\
\hline PAAG_01995 & fructose-bisphosphate aldolase & $14,297.79$ \\
\hline PAAG_02585 & triosephosphate isomerase * & $12,564.27$ \\
\hline PAAG_02869 & phosphoglycerate kinase & $12,361.49$ \\
\hline PAAG_06380 & pyruvate kinase & 8237.422 \\
\hline PAAG_00726 & pyruvate carboxylase & 5375.759 \\
\hline \multirow[t]{2}{*}{ PAAG_08203 } & phosphoenolpyruvate carboxykinase & 4991.925 \\
\hline & Tricarboxylic-acid pathway & \\
\hline PAAG_01534 & $\begin{array}{c}\text { pyruvate dehydrogenase E1 component } \\
\text { subunit beta }\end{array}$ & 3429.868 \\
\hline PAAG_07729 & isocitrate dehydrogenase subunit 2 & 4581.662 \\
\hline PAAG_08449 & malate dehydrogenase & 3811.987 \\
\hline PAAG_00053 & malate dehydrogenase & 2309.6 \\
\hline \multirow[t]{2}{*}{ PAAG_05048 } & 3-isopropylmalate dehydratase large subunit & 3299.345 \\
\hline & Electron transport & \\
\hline \multirow[t]{2}{*}{ PAAG_04820 } & ATPase alpha subunit & 4619.729 \\
\hline & Respiration & \\
\hline PAAG_08037 & ATP synthase subunit beta & 4555.649 \\
\hline PAAG_00953 & NADH-cytochrome b5 reductase & 2806.097 \\
\hline PAAG_00173 & electron transfer flavoprotein subunit alpha & 3309.523 \\
\hline PAAG_02265 & mitochondrial F1F0 ATP synthase subunit & $14,297.79$ \\
\hline
\end{tabular}


Table 1. Cont.

\begin{tabular}{|c|c|c|}
\hline Accession & Protein Name & Score $* *$ \\
\hline \multicolumn{3}{|c|}{ Pentose-phosphate pathway } \\
\hline PAAG_04166 & transaldolase & $12,361.49$ \\
\hline PAAG_04444 & transketolase & 8237.422 \\
\hline \multicolumn{3}{|c|}{ Energy conversion and regeneration } \\
\hline PAAG_03631 & 12-oxophytodienoate reductase * & 4991.925 \\
\hline \multicolumn{3}{|c|}{ Yeast } \\
\hline & Glycolysis and Gluconeogenesis & \\
\hline PAAG_06526 & glucose-6-phosphate isomerase & $44,267.03$ \\
\hline PAAG_01583 & phosphofructokinase 1 & $30,114.88$ \\
\hline PAAG_01995 & fructose-bisphosphate aldolase & $24,984.16$ \\
\hline PAAG_02585 & triosephosphate isomerase * & $22,256.77$ \\
\hline PAAG_08468 & glyceraldehyde-3-phosphate dehydrogenase * & $20,333.02$ \\
\hline PAAG_02869 & phosphoglycerate kinase & $18,095.4$ \\
\hline PAAG_06380 & pyruvate kinase & $20,228.38$ \\
\hline PAAG_02512 & pyruvate decarboxylase * & $18,851.39$ \\
\hline PAAG_02050 & pyruvate decarboxylase * & $18,717.38$ \\
\hline PAAG_00726 & pyruvate carboxylase & $13,367.75$ \\
\hline PAAG_08203 & phosphoenolpyruvate carboxykinase & $23,108.45$ \\
\hline PAAG_02682 & fructose-1.6-bisphosphatase & $14,274.43$ \\
\hline PAAG_07986 & phosphofructokinase 2 & $16,924.33$ \\
\hline PAAG_07410 & $\begin{array}{l}\text { 2,3-bisphosphoglycerate-independent } \\
\text { phosphoglycerate mutase }\end{array}$ & $15,371.76$ \\
\hline \multicolumn{3}{|c|}{ Tricarboxylic-acid pathway } \\
\hline PAAG_00094 & pyruvate dehydrogenase kinase & $11,769.04$ \\
\hline PAAG_01534 & $\begin{array}{l}\text { pyruvate dehydrogenase E1 component } \\
\text { subunit beta }\end{array}$ & $13,649.55$ \\
\hline PAAG_08295 & $\begin{array}{c}\text { pyruvate dehydrogenase E1 component } \\
\text { subunit alpha }\end{array}$ & $13,423.09$ \\
\hline PAAG_02769 & pyruvate dehydrogenase protein $X$ component & $14,287.29$ \\
\hline PAAG_03330 & dihydrolipoyl dehydrogenase & $11,642.86$ \\
\hline PAAG_08915 & dihydrolipoamide succinyltransferase & $14,385.67$ \\
\hline PAAG_01725 & succinate dehydrogenase flavoprotein subunit & 9554.287 \\
\hline PAAG_04238 & succinate dehydrogenase flavoprotein subunit & 9647.347 \\
\hline PAAG_06103 & succinate dehydrogenase iron-sulfur subunit & $12,727.08$ \\
\hline PAAG_00417 & succinyl-CoA ligase subunit alpha & 7841.01 \\
\hline PAAG_01463 & succinyl-CoA ligase subunit beta & 9100.539 \\
\hline PAAG_00856 & isocitrate dehydrogenase subunit 1 & $11,681.96$ \\
\hline PAAG_07729 & isocitrate dehydrogenase subunit 2 & $10,708.71$ \\
\hline PAAG_08351 & $\begin{array}{c}\text { mitochondrial NADP-specific isocitrate } \\
\text { dehydrogenase }\end{array}$ & $13,966.9$ \\
\hline PAAG_00053 & malate dehydrogenase & $10,102.86$ \\
\hline PAAG_08449 & malate dehydrogenase & 8959.159 \\
\hline PAAG_05150 & ATP-citrate synthase subunit 1 & $10,582.24$ \\
\hline PAAG_05151 & ATP-citrate-lyase & $10,356.12$ \\
\hline PAAG_08075 & citrate synthase & 9238.283 \\
\hline PAAG_07843 & aconitase & $12,099.61$ \\
\hline PAAG_05048 & 3-isopropylmalate dehydratase large subunit * & $10,060.89$ \\
\hline PAAG_00588 & fumarate hydratase & 9309.173 \\
\hline PAAG_02732 & 2-oxoglutarate dehydrogenase E1 & $10,540.35$ \\
\hline
\end{tabular}


Table 1. Cont.

\begin{tabular}{|c|c|c|}
\hline Accession & Protein Name & Score $* *$ \\
\hline \multicolumn{3}{|c|}{ Electron transport } \\
\hline PAAG_03051 & $\begin{array}{c}\text { NADH-ubiquinone oxidoreductase } 20.8 \mathrm{kDa} \\
\text { subunit }\end{array}$ & $10,945.87$ \\
\hline PAAG_01044 & $\begin{array}{c}\text { NADH-ubiquinone oxidoreductase } 24 \mathrm{kDa} \\
\text { subunit }\end{array}$ & 8694.258 \\
\hline PAAG_05031 & $\begin{array}{c}\text { NADH-ubiquinone oxidoreductase } 40 \mathrm{kDa} \\
\text { subunit }\end{array}$ & 7284.236 \\
\hline PAAG_05735 & $\begin{array}{c}\text { NADH-ubiquinone oxidoreductase } 49 \mathrm{kDa} \\
\text { subunit }\end{array}$ & 8447.485 \\
\hline PAAG_02656 & $\begin{array}{c}\text { NADH-ubiquinone oxidoreductase } 51 \mathrm{kDa} \\
\text { subunit }\end{array}$ & 9802.509 \\
\hline PAAG_07791 & NADH-ubiquinone oxidoreductase & 8821.187 \\
\hline PAAG_08916 & LYR family protein & 7664.982 \\
\hline PAAG_04820 & ATPase alpha subunit & 7938.354 \\
\hline \multicolumn{3}{|c|}{ Respiration } \\
\hline PAAG_08037 & ATP synthase subunit beta & 7580.651 \\
\hline PAAG_05576 & ATP synthase gamma chain & 6790.638 \\
\hline PAAG_04570 & ATP synthase D chain mitochondrial & $44,267.03$ \\
\hline PAAG_04838 & ATP synthase subunit 4 & $30,114.88$ \\
\hline PAAG_02679 & vacuolar ATP synthase $98 \mathrm{kDa}$ subunit & $24,984.16$ \\
\hline PAAG_08966 & $\begin{array}{c}\text { NADH-ubiquinone oxidoreductase } 78 \mathrm{kDa} \\
\text { subunit }\end{array}$ & $22,256.77$ \\
\hline PAAG_02266 & $\begin{array}{c}\text { NADH-ubiquinone oxidoreductase } 21 \mathrm{kDa} \\
\text { subunit }\end{array}$ & $20,333.02$ \\
\hline PAAG_00953 & NADH-cytochrome b5 reductase & $18,095.4$ \\
\hline PAAG_08088 & cytochrome b-c1 complex subunit 2 & $20,228.38$ \\
\hline PAAG_08057 & cytochrome c oxidase polypeptide $\mathrm{V}$ & $18,851.39$ \\
\hline PAAG_06796 & cytochrome $\mathrm{c}$ oxidase subunit $5 \mathrm{~b}$ & $18,717.38$ \\
\hline PAAG_03292 & cytochrome c peroxidase & $13,367.75$ \\
\hline PAAG_00173 & electron transfer flavoprotein subunit alpha & $23,108.45$ \\
\hline PAAG_04931 & electron transfer flavoprotein subunit beta & $14,274.43$ \\
\hline PAAG_02265 & mitochondrial F1F0 ATP synthase subunit & $16,924.33$ \\
\hline PAAG_01078 & alternative oxidase & $15,371.76$ \\
\hline \multicolumn{3}{|c|}{ Methylcitrate cycle } \\
\hline PAAG_04549 & mitochondrial 2-methylisocitrate lyase & $11,769.04$ \\
\hline PAAG_04550 & 2-methylcitrate synthase * & $13,649.55$ \\
\hline PAAG_04559 & 2-methylcitrate dehydratase * & $13,423.09$ \\
\hline \multicolumn{3}{|c|}{ Propionate metabolism } \\
\hline \multicolumn{3}{|c|}{ Pentose-phosphate pathway } \\
\hline PAAG_04444 & transketolase & 9554.287 \\
\hline PAAG_04166 & transaldolase & 9647.347 \\
\hline \multicolumn{3}{|c|}{ Glyoxylate cycle } \\
\hline PAAG_04542 & malate synthase & 7841.01 \\
\hline PAAG_07786 & acetyl-CoA acetyltransferase & 9100.539 \\
\hline & Energy conversion & \\
\hline PAAG_03631 & 12-oxophytodienoate reductase * & $10,708.71$ \\
\hline
\end{tabular}

Functional classification by FunCat2, (http://pedant.gsf.de/pedant3htmlview/pedant3view?Method=analysis\& $\mathrm{Db}=\mathrm{p3}$ _r48325_Par_lutzi), * Proteins that formed multiprotein complex with P. lutzii ICL in a BN-PAGE assay. ** The confidence of each identification is evaluated by the estimated probability of the correct-match distribution.

Correct and reversed sequences databases were used to estimate false-positive rates (FPR). Using protein identification replication as a filter, the false-positive rate was minimized because false-positive protein identification, i.e., chemical noise, has a random nature and does not tend 
to replicate across injections. For the analysis of the protein identification and quantification level, the observed intensity measurements were normalized to the intensity measurement of the identified peptides of the digested internal standard [Glu] $]^{1}$-Fibrinopeptide B (GluFib) (Sigma, St. Louis, MO, USA). Peptides and protein tables were generated by ProteinLynx Global Server (PLGS), as previously described [37]. Microsoft Excel (Microsoft, Washington, DC, USA) was used for table manipulations; Uniprot (http://www.uniprot.org) and Pedant on MIPS (http://mips.helmholtz-muenchen.de/funcatDB/) database were used for functional classification; uncharacterized proteins were annotated using NCBI database (https://www.ncbi.nlm.nih.gov/).

\subsection{Co-Immunoprecipitation}

The assay was performed according to [38] with some modifications. Briefly, target antibodies were incubated with protein A sepharose 4B (Invitrogen, Waltham, MA, USA) for $3 \mathrm{~h}$. Then, the solution antibodies and resin were incubated with $3 \mathrm{mg} / \mathrm{mL}$ of total protein extract for $3 \mathrm{~h}$. Washing steps were performed with wash solution, $10 \mathrm{~m} \mathrm{mM}$ tris at $\mathrm{pH} 7.4,1 \%$ Triton and $1 \mathrm{mM}$ EDTA (ethylenediamine tetraacetic acid). Elution was performed with $0.2 \mathrm{M}$ glycine at $\mathrm{pH} 2.6$ and equal amount of $0.2 \mathrm{M}$ tris at $\mathrm{pH}$ 8.0. Eluted samples underwent SDS (sodium dodecyl sulfate)-PAGE followed by Western blot.

\subsection{STRING Database Analysis}

The STRING (Search Tool for the Retrieval of Interacting Genes/Proteins) database maintains PPI data regarding both physical and functional interactions. The tool combines data from a large variety of sources such as textmining, laboratory experiments, co-expression and computational PPI prediction [39]. STRING was used to search for ICL interactions in P. lutzii with the highest confidence score (0.900). We used the latest version 11.0 (http://string.embl.de).

\subsection{D Structures Assembly}

The 3D structure of $P$. lutzii ICL and its interactors have not been resolved experimentally to this date. Hence, all the amino acid sequences were compared against the PDB using the I-TASSER server (http: //zhanglab.ccmb.med.umich.edu/I-TASSER/) [40]. The server performs the modeling on templates based on homology of proteins with experimental structures that are available in the PDB. The quality of the 3D structures was evaluated by the MolProbity server (http://molprobity.biochem.duke.edu/). The model quality evaluation relies on the global and local levels of the analyzed proteins and on the power and sensitivity supplied by the optimized hydrogen placement, atom contact analysis, covalent-geometry and torsion-angle criteria [41]. The root mean square deviation (RMSD), Ramachandran and cluster graphics of the ICL 3D model were published in another approach performed by our group [42].

\subsection{Molecular Dynamics}

Molecular dynamics (MD) simulations were performed using the software GROMACS 4.5.5, AMBER force field (200 ns; $\mathrm{Mg}^{2+}$ ), with explicit solvent (water TIP3P) in order to get a more stable protein structure and most similar to the ICL native conformation. The process solvates the 3D models in a cubic box within the defined force field, tending to improve electrostatic interactions with periodic boundary conditions in all directions of the box [43]. In the first step of the MD, the overall system was balanced through the addition of ions in order to minimize energy variation. Simulations were allowed until the system reached the tolerant limit of $1000 \mathrm{KJ} / \mathrm{mol}$. Any simulation with excessive energy or simulations with atoms that overlap were discarded. The system was then equilibrated through energy relaxation for $100 \mathrm{ps}$ and then simulations were performed at $300 \mathrm{~K}, 1 \mathrm{~atm}$ and time interval of $2 \mathrm{fs}$ without any restriction in the protein conformation.

MD trajectories were assessed every 5 ps and the equilibrium of the trajectories was monitored through RMSD considering non-hydrogen atoms and compared to the initial conformation. The evolution of the overall energy (potential and kinetic altogether) was assessed using GROMACS package [44]. The RMSD graphic shows values from template structures and is used to identify common 
segments related to structurally conserved regions among simulations, thus the most representative conformational was selected to undergo molecular docking [45].

\subsection{Molecular Docking}

The GRAMM-X protein-protein anchor server (http://vakser.compbio.ku.edu/resources/gramm/ grammx/) was used in order to identify the best dual protein complex conformation between P. lutzii ICL and interacting proteins [46]. Then, the amino acids involved in the interaction were identified. KFC2 server (https://mitchell-lab.biochem.wisc.edu/KFC_Server/index.php) was used to recognize the contact residues in the interaction interface of ICL and binding proteins [47]. CoCoMAPS (https://www.molnac.unisa.it/BioTools/cocomaps/) server was applied to analyze the interface of the protein complexes through intermolecular contact maps. Thus, it was identified residues of the binding proteins that interact with ICL and it was possible to categorize them as hotspots [48]. The ICL regions most frequently involved in the interactions were proposed based on the most frequent interacting residues.

\section{Results and Discussion}

\subsection{ICL Interacts with Proteins from the Glycolytic Pathway}

According to the pull-down assay, ICL interacted with 18 proteins in mycelium, 19 proteins in mycelium-to-yeast transition and 70 proteins related to energetic metabolism in yeast (Table 1). Figure 1 shows the number of proteins that interact with ICL in mycelium, mycelium-to-yeast transition and yeast cells.

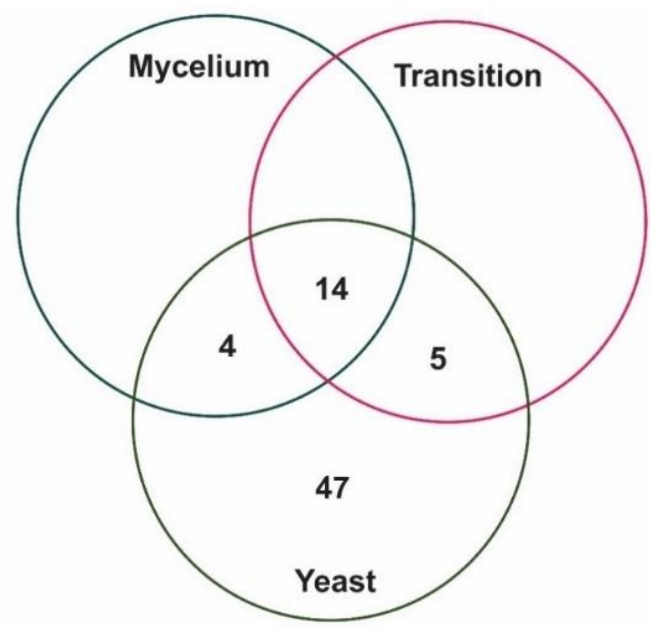

Figure 1. Venn diagram of proteins that interact with ICL. No specific mycelium and mycelium-to-yeast transition proteins were found binding to ICL and 47 proteins were found interacting to ICL specifically in the yeast phase. Yeast proteins are very active in the anaerobic metabolism and ICL interactions may take part in the regulation of both aerobic and anaerobic metabolism.

Among proteins that bound to ICL in the pull-down assay, phosphoenolpyruvate carboxykinase (PEPCK), 2-methylcitrate dehydratase (2MDH), 2-methylcitrate synthase (MCS), 12-oxophytodienoate reductase (OPR), glyceraldehyde-3-phosphate dehydrogenase (GAPDH), enolase, among others, were validated by the BN-PAGE approach. MCS was also validated by co-immunoprecipitation, along with glyceraldehyde-3-phosphate dehydrogenase, triosephosphate isomerase (TPI) and enolase (ENO) (Figure 2). 


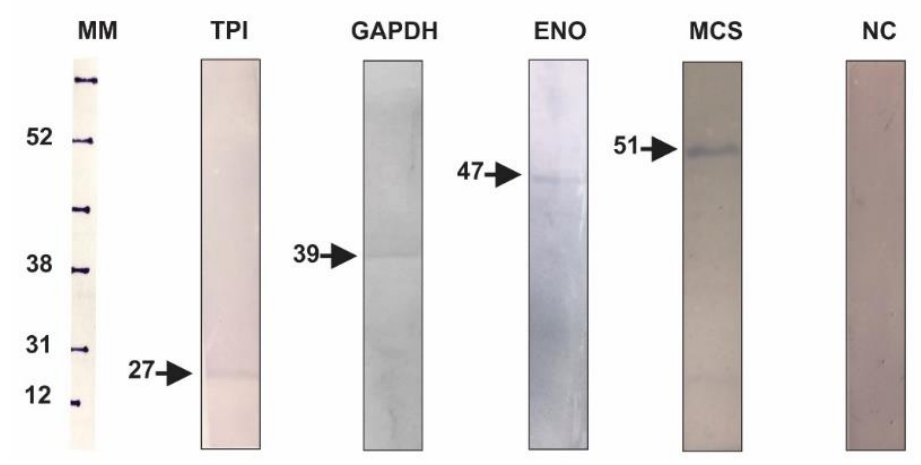

Figure 2. Validation of ICL interacting proteins by the co-immunoprecipitation assay. Here, anti-ICL antibody was incubated with protein A sepharose 4B and then with P. lutzii total protein extract. Eluted samples underwent SDS-PAGE followed by Western blot. TPI (triose phosphate isomerase; $27 \mathrm{KDa}$ ), GAPDH (glyceraldehyde-3-phosphate dehydrogenase; $39 \mathrm{KDa}$ ); ENO (enolase; $47 \mathrm{KDa}$ ), MCS (2-methylcitrate synthase; $51 \mathrm{KDa}$ ) and NC (negative control). MM-rainbow molecular marker, Amersham ${ }^{\mathrm{TM}}$. MCS and GAPDH were identified from the yeast phase, ENO from mycelium-to-yeast transition and TPI from the mycelium phase. The antibodies anti-MCS [49], anti-GAPDH [50], anti-ENO [51] and anti-TPI [52] were produced by our laboratory group. The interaction between ICL and MCS, GAPDH and TPI were identified both by chromatography and BN-PAGE and the interaction between ICL and ENO was identified by BN-PAGE.

There is a connection among the major energetic metabolic pathways: glycolysis, gluconeogenesis, TCA, glyoxylate and methylcitrate cycles. The expression of certain enzymes from a cycle may inhibit the activity of enzymes from others [53]. In photosynthetic organisms, for example, reactions of the glyoxylate cycle couple with reactions of TCA to feed intermediates into gluconeogenesis. A null ICL mutation in Chlamydomonas was performed in order to analyze the effects of ICL absence in carbon metabolism [54]. They realized that ICL deletion decreased the amount of glycolysis and gluconeogenesis enzymes. Here, ICL interacted with fructose-bisphosphate aldolase (FBPA), PEPCK, phosphofructokinase 1 (PFK1), glucose-6-phosphate isomerase (GPI) and pyruvate kinase (PK; Figure 3), the very same enzymes were down-regulated in the absence of ICL expression in Chlamydomonas.

ICL interacted with TPI (Figure 3) in all experimental approaches we performed. In addition, this interaction was validated by co-immunoprecipitation (Figure 2). ICL is a potential target for drug design against several microorganisms, including M. tuberculosis [55]. Britton and colleagues (2000) worked with a rational drug design based on the structure of Aspergillus nidulans ICL. They found that ICL structure has a TPI similar motif and they share similar interaction interfaces [56]. In multiprotein complexes, common interaction partners are prone to interact through similar interfaces which are usually related to a common motif among those proteins [57].

Phosphoglycerate kinase (PGK) and PFK1 (Figure 3) interacted with ICL according to our pull-down assay (Table 1) and the latter is a regulatory protein from the glycolytic pathway. ICL influences the activity of certain glycolytic enzymes [54]. In addition, it has been shown that some products of glycolytic reactions can inhibit ICL activity [58]. The product of PGK activity is 3-phosphoglycerate and fructose-1,6-bisphosphate is the product of PFK1. Both inhibited ICL activity efficiently in Corynebacterium glutamicum, showing that these enzymes have a role in controlling the energetic metabolism of cells. Interestingly, ICL may participate in the regulation of energetic metabolism and influence the production or consumption of ATP in pathways, such as glycolysis. We found two glycolytic enzymes that undergo allosteric regulation, PFK1 and PGK [59], and their interaction with ICL may affect $P$. lutzii metabolism driving it either to aerobic (mycelium phase) or anaerobic (yeast phase) conditions. 


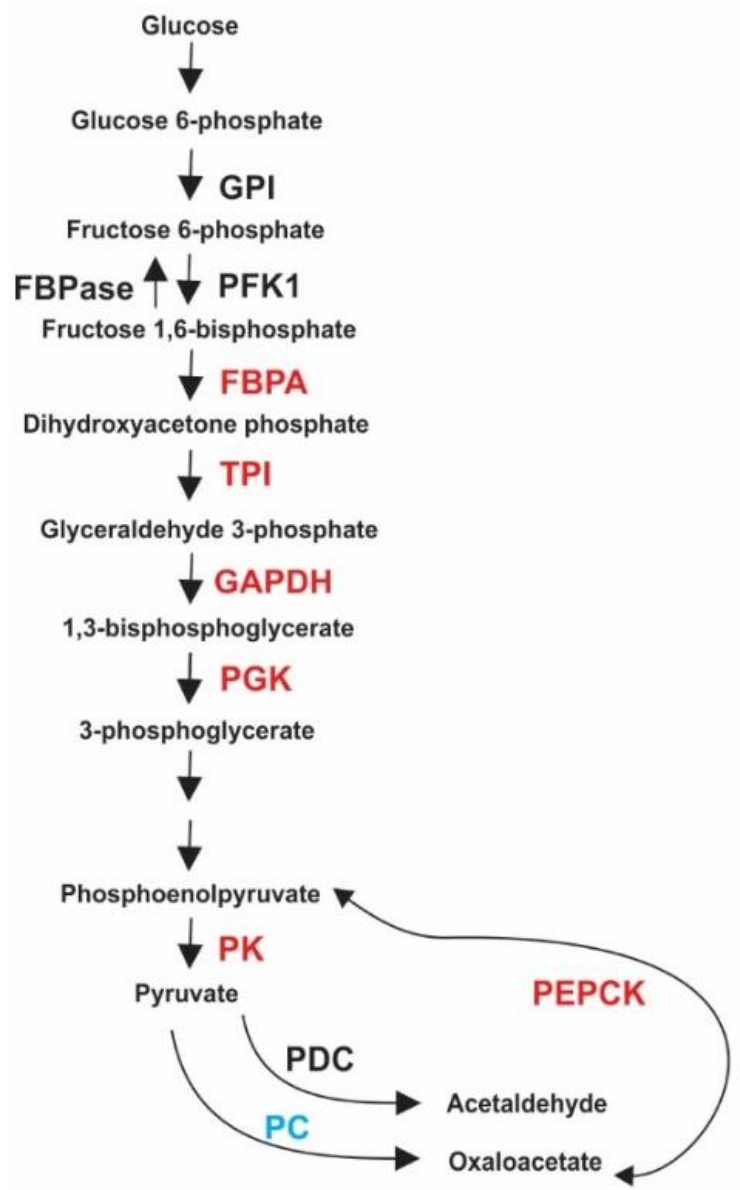

Figure 3. Proteins from glycolysis and gluconeogenesis that interacted with P. lutzii ICL. Proteins in black are specific from yeast cells, red refers to proteins that are common to mycelium, mycelium-to-yeast transition and yeast cells. Blue refers to proteins that are common to mycelium-to-yeast transition and yeast cells. No proteins were common to mycelium and mycelium-to-yeast transition. GPI (glucose-6-phosphate isomerase); FBPase (fructose-1,6-bisphosphatase); PFK1 (phosphofructokinase 1); FBPA (fructose-bisphosphate aldolase); TPI (triosephosphate isomerase); GAPDH (glyceraldehyde-3-phosphate dehydrogenase); PGK (phosphoglycerate kinase); PK (pyruvate kinase); PDC (pyruvate decarboxylase); PC (pyruvate carboxylase); PEPCK (phosphoenolpyruvate carboxykinase).

Phosphoenolpyruvate is produced from pyruvate during gluconeogenesis. First, pyruvate carboxylase (PC) irreversibly converts pyruvate into oxaloacetate, which is then converted into phosphoenolpyruvate by PEPCK (Figure 3). Overexpression of ICL recovered growth of PC mutant cells. They showed that ICL is involved in anaplerotic reactions of phosphoenolpyruvate and oxaloacetate, which are important for gluconeogenesis [60]. Enzymes from the glyoxylate cycle and TCA are required for a proper function of gluconeogenesis [61]. Fructose-1,6-bisphosphatase (FBPase), ICL and PEPCK are secreted in Saccharomyces cerevisiae grown in low glucose [62] showing that these proteins take part in the metabolic shift of fungal cells. These experimental pieces of evidence show that the relation between energetic metabolic enzymes are rather intricate and complex, highlighting a great potential of cell metabolism for adaptation to several conditions and perturbations.

There are some similarities between ICL and PEPCK. Both enzymes are essential for certain pathogens, such as $M$. tuberculosis, to grow inside macrophages [63]. ICL influences several metabolic pathways such as glycolysis, gluconeogenesis and TCA, this way the enzyme roles would be more complex than only being related to a metabolic shift from carbohydrates to fatty acids during the host-pathogen interaction [64]. Interestingly, we found P. lutzii ICL interacting with proteins from 
all of those metabolic pathways (Table 1). ICL could play anabolic roles, since its flux reactions do not feed TCA for catabolism but for biosynthesis through the succinyl-CoA node [64]. There is also evidence that ICL and PEPCK influence gluconeogenesis in plants $[65,66]$. Interaction between ICL, PEPCK and other proteins from glycolysis and gluconeogenesis may be important to regulate central metabolism in P. lutzii, since it is well known that in Paracoccicioidies, the yeast phase is preferably grown in anaerobic conditions and mycelium phase in aerobic conditions [5].

Figure 3 schematically shows proteins related to glycolysis that interacted with ICL in the pull-down assay and some of the multiprotein complexes ICL forms were validated by BN-PAGE. Here, ICL may play important roles regulating glycolysis and gluconeogenesis. Moreover, ICL interacts with enzymes that are points of regulation of glycolysis such as PFK1 and PK. As ICL is related to a metabolic shift [64], it might as well regulate proteins in these pathways to drive aerobic metabolism to mycelium cells and anaerobic metabolism to yeast cells.

\subsection{ICL Influences TCA Flux and Electron Chain Dynamics}

The ICL activity and its importance to certain pathogens survival and persistence within host cells are related to its role in the glyoxylate shunt, which provides a metabolic shift in the principal carbon source from carbohydrates into fatty acids [67]. The glyoxylate shunt function as an anaplerotic pathway necessary for the metabolism of fatty acids but can also function in more general conditions, such as influencing oxidative reactions of TCA [68].

In an ICL deleted $M$. tuberculosis mutant, TCA intermediates were down-regulated when compared to wild-type cells and they showed accumulation of propionate due to the metabolism of fatty acids [69]. The authors suggested that the absence of ICL might have impaired respiratory processes due to TCA intermediate depletion and alteration of the methylcitrate cycle. Our results show P. lutzii ICL interacting with proteins from all of those pathways (Table 1; Figure 4), and we hypothesize that P. lutzii ICL might act as a regulator of TCA anaplerotic reactions and it also influences respiratory activities.

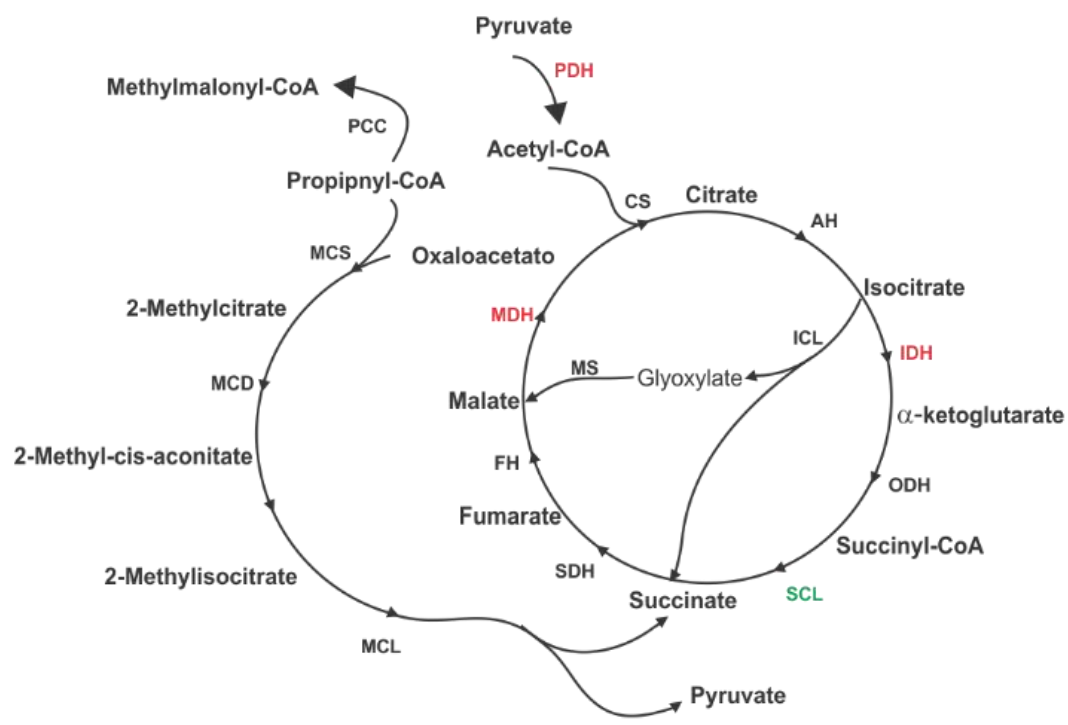

Figure 4. The diagram shows proteins from TCA, glyoxylate shunt and methylcitrate cycle that interacted with ICL. Most of the proteins were identified in the pull down performed on yeast cells (protein in black), only MDH (malate dehydrogenase), IDH (isocitrate dehydrogenase) and $\mathrm{PDH}$ (pyruvate dehydrogenase) were found in the pull down of protein extracts from mycelium, mycelium-to-yeast transition and yeast cells (proteins in red). SCL (succinyl-CoA ligase) was found in protein extract from mycelium and yeast cells (proteins in green). CS (citrate synthase); AH (aconitase); ODH (2-oxoglutarate dehydrogenase); SDH (succinate dehydrogenase); FH (fumarate hydratase); PCC (propionyl-CoA carboxylase); MCS (2-methylcitrate synthase); MCD (2-methylcitrate dehydratase); MCL (mitochondrial 2-methylisocitrate lyase). 
The state of fragility regarding accumulation of propionate is not only related to the absence of ICL activity but due to metabolic flaws such as derangement of methylcitrate cycle, less amount of oxaloacetate from the TCA and the gluconeogenic pathways. ICL interacted with mitochondrial 2-methylisocitrate lyase (MCL), MCS and 2-MDH from methylcitrate cycle and with malate dehydrogenase (MDH) from TCA (Tables 1 and 2; Figure 4). These interactions may help to control the energetic metabolism in pathogen cells to eliminate propionate and maintain a normal level of anaplerotic constituents. Interestingly, accumulation of methylmalonyl-CoA due to partial degradation of propionyl-CoA by propionyl-CoA carboxylase was observed [69] and we found ICL interacting with this protein as well (Figure 4). Finally, studies on the effects of ICL overexpression resulted in a higher degree of oxidative TCA reactions with higher production of succinate, fumarate, citrate and oxaloacetate [70]. P. lutzii ICL interacted with enzymes responsible for the production of such intermediates: succinyl-CoA ligase, succinate dehydrogenase, citrate synthase and MDH (Tables 1 and 2; Figure 4).

Table 2. Validation of the chromatographic assay of ICL interacting proteins from mycelium, mycelium-to-yeast transition and yeast cells according to STRING.

\begin{tabular}{|c|c|c|}
\hline Accession Number & Protein Name & Score \\
\hline PAAG_04542 & malate synthase * & 0.998 \\
\hline PAAG_05048 & $\begin{array}{l}\text { 3-isopropylmalate dehydratase large } \\
\text { subunit \# }\end{array}$ & 0.983 \\
\hline PAAG_03138 & alanine-glyoxylate aminotransferase \& & 0.943 \\
\hline PAAG_02682 & fructose-1,6-bisphosphatase * & 0.933 \\
\hline PAAG_08203 & phosphoenolpyruvate carboxykinase \# & 0.926 \\
\hline PAAG_07725 & peroxisomal (S)-2-hydroxy-acid oxidase \& & 0.911 \\
\hline PAAG_03793 & dihydrodipicolinate synthase \& & 0.900 \\
\hline PAAG_08075 & citrate synthase * & 0.899 \\
\hline PAAG_04550 & 2-methylcitrate synthase * & 0.858 \\
\hline PAAG_06563 & $\begin{array}{l}\text { succinate/fumarate mitochondrial } \\
\text { transporter \& }\end{array}$ & 0.835 \\
\hline PAAG_02653 & acetyl-coenzyme A synthetase \& & 0.827 \\
\hline PAAG_04549 & mitochondrial 2-methylisocitrate lyase * & 0.819 \\
\hline PAAG_02361 & D-amino-acid oxidase \& & 0.816 \\
\hline PAAG_04751 & hypothetical protein \& & 0.800 \\
\hline PAAG_11872 & hypothetical protein \& & 0.785 \\
\hline PAAG_03275 & molybdenum cofactor sulfurase \& & 0.757 \\
\hline PAAG_08859 & peroxisomal multifunctional enzyme \& & 0.735 \\
\hline PAAG_00053 & malate dehydrogenase * & 0.733 \\
\hline PAAG_02585 & triosephosphate isomerase * & 0.678 \\
\hline PAAG_01995 & fructose-bisphosphate aldolase $1 *$ & 0.676 \\
\hline PAAG_06224 & carnitine O-acetyltransferase $\&$ & 0.663 \\
\hline PAAG_00726 & pyruvate carboxylase $^{\$}$ & 0.662 \\
\hline PAAG_02732 & 2-oxoglutarate dehydrogenase E1 $\S$ & 0.649 \\
\hline PAAG_04851 & osmotic growth protein \# & 0.649 \\
\hline PAAG_07729 & isocitrate dehydrogenase * & 0.638 \\
\hline PAAG_11349 & peroxisomal biogenesis factor 6 \& & 0.626 \\
\hline PAAG_01015 & Hexokinase \& & 0.624 \\
\hline PAAG_08449 & malate dehydrogenase * & 0.621 \\
\hline PAAG_0058 & fumarate hydratase * & 0.607 \\
\hline PAAG_04856 & acetyl-CoA hydrolase & 0.605 \\
\hline PAAG_08057 & cytochrome c oxidase * & 0.602 \\
\hline
\end{tabular}

* Proteins specific from yeast protein extract; ${ }^{*}$ Proteins common to mycelium, mycelium-to-yeast transition and yeast protein extracts; ${ }^{\&}$ Proteins specific from STRING database; $\$$ Proteins common to mycelium-to-yeast transition and yeast.

TCA and glyoxylate cycles enzymes are under investigation and new functions for such enzymes have been proposed. Isocitrate dehydrogenase (IDH) and ICL, for example, were found to be related to riboflavin production, which also uses TCA intermediates such as malate. Disruption of the genes that 
encode for IDH and ICL led to a significant decrease in riboflavin levels [71]. Here, ICL interacted with IDH and other proteins from TCA, showing that it may play important roles in central metabolism of Paracoccidioides. The relationship between the two specific enzymes of glyoxylate cycle has also been investigated. In Caenorhabditis elegans and Euglena gracilis, ICL and MLS are expressed as a single bifunctional polypeptide being encoded by a single gene [72,73]. We found ICL interacting with MLS in P. lutzii (Table 1) and their interaction may promote substrate channeling, which could raise the concentration of enzymatic intermediates and reduce the concentration of enzyme required to maintain the intermediate flux in that pathway. Most importantly, the final product is driven in a scaffold manner to a specific subcellular location preventing loss of such intermediates [74].

Aconitase (AH) catalyzes the isomerization of citrate to isocitrate. The latter can be used either in the glyoxylate shunt or in TCA by ICL or IDH, respectively. ICL interacted with AH and IDH (Tables 1 and 2) in the pull-down assay (Figure 4). These proteins play important roles in driving the metabolism of cells towards aerobic or anaerobic conditions. Over the decades, biotechnological studies have attempted to change the level of anaplerotic products produced by microorganisms through deletion of genes involved in the TCA cycle and the glyoxylate shunt due to the involvement of the enzymes from these pathways in the aerobic and anaerobic metabolism $[75,76]$. The relation of the TCA cycle and the glyoxylate shunt in the production of succinate has been investigated. According to previous knowledge, S. cerevisiae cells produce succinate via oxidative reactions of TCA and the glyoxylate shunt. AH and ICL double mutants inhibited oxidative reactions of those pathways. Double mutants showed a slower growth rate compared to control due to defect in catabolizing carbon compounds. The deletion also altered fermentation properties of the cells with lower production of succinate [77]. This is another indication that ICL influences central metabolism and may play important metabolic roles in P. lutzii besides participating in the conversion of acetyl-CoA to succinate for the synthesis of carbohydrates.

ICL interacted with several enzymes that take part in the electron transport chain and respiration (Tables 1 and 2). ICL deletion mutants have anaplerotic intermediates imbalance and the accumulation of certain compounds, such as propionate, as discussed previously. This leads to changes in the $\mathrm{NAD} / \mathrm{NADH}$ ratio, consequently altering $\mathrm{pH}$ and the membrane potential responsible for the generation of intracellular ATP. Some authors have suggested that ICL could play important roles in maintaining the balance between glycolysis, TCA and respiratory chain in order to maintain an energized and functional membrane for energy generating processes [69]. Proteins act within interconnected pathways and networks that evolved over the years in order to be robust and give cells the ability to adapt more and more to the environment. Thus, identifying metabolons and new PPIs might shed light on specific biochemical pathways associated with a given phenotype or perturbation such as the microenvironment of a macrophage.

Figure 4 shows proteins from TCA and methylcitrate cycle that interacted with ICL. The glyoxylate shunt enzymes, mainly ICL, take part in anaplerotic pathways required primarily for the metabolism of fatty acids. They can also affect general conditions, such as the reactions of TCA and consequently the respiratory chain. Here, we hypothesize that ICL might act as one of the regulators of TCA anaplerotic reactions, methylcitrate cycle and respiratory chain.

\subsection{STRING PPI Database Validates ICL Protein Partners from Pull-Down Assay}

We compared our results with ICL binding proteins in the STRING database. According to STRING, 31 proteins interact with P. lutzii ICL. The PPI prediction score generated by STRING ranged from 0.600 to 0.998 . Among those proteins, 16 interacted with ICL from yeast cells, none in mycelium cells and one in mycelium-to-yeast transition cells (Table 2 and Supplementary Figure S1). There were 15 proteins identified in the STRING databank that were not found in our results, probably because the techniques used might disrupt weak and transient interactions [78].

Only four proteins showed scores higher than 0.900 and among them 3-isopropylmalate dehydratase large subunit (IMDH) and MLS (Figure 5) were found in our experimental approaches. 
Interestingly, all proteins bound to ICL either in mycelium or in mycelium-to-yeast transition phases were also bound to ICL in the yeast phase according to STRING. To our knowledge, no study has been performed focusing on the comparison of PPIs in different phases of dimorphic microorganisms.

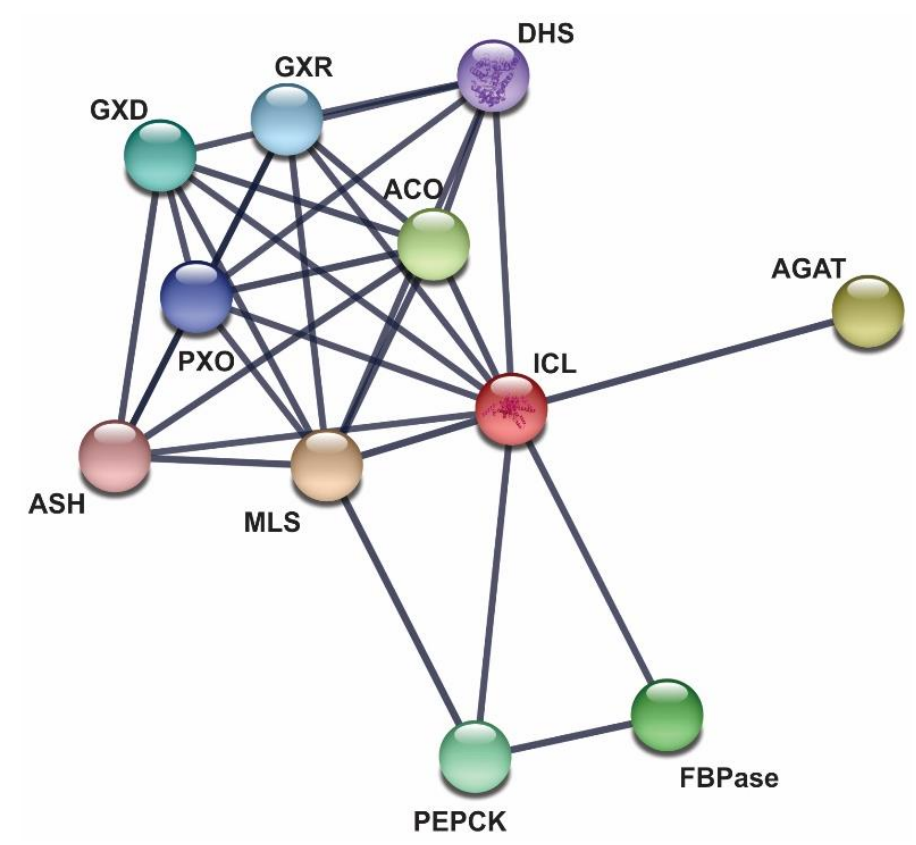

Figure 5. ICL interacting proteins according to STRING database. STRING identified ten P. lutzii ICL partners [39] when the score selected was of the highest confidence (0.9). This database collects data textmining, laboratory experiments, co-expression and computational PPI prediction sources. The types of interaction were hypothetical for ASH and DHS and homolog expression for all the other ICL partners identified by STRING. ACO (aconitate hydratase), DHS (dihydrodipicolinate synthase), GXR (glyoxylate reductase), PXO (peroxisomal oxidase), GXD (glyoxylate dehydrogenase), MLS (malate synthase), (PEPCK) phosphoenolpyruvate carboxykinase, FBPase (fructose-1,6-bisphosphatase), ASH (aspartate-4-semialdehyde hydrolase) and AGAT (alanine-glyoxylate aminotransferase).

\subsection{P. lutzii ICL Has Several Regions of Interaction Interface}

The KFC-2 server provided means to identify the most common residues involved in the interaction of ICL with other proteins. Finding hot spots on the protein surface has shed light on experimental applications in the biological fields [79-81] and understanding PPIs means understanding proteins' biological functions. Here, we used this approach in order to identify the main contact preference regions of $P$. lutzii ICL when it interacted with proteins from mycelium, mycelium-to-yeast and yeast phases. Moreover, the technique has been applied for different purposes such as rational drug design [79], understanding the physiology of transient PPIs [82] and the understanding of specific virulence mechanisms in pathogens [83].

We selected 15 proteins for this in silico analysis. Among them, 10 ICL binding proteins related to central metabolism (Figure 6A-J) since ICL interferes with it in a variety of pathogens [54,64]. Proteins from secondary metabolism formed the other complexes (Figure $6 \mathrm{~K}-\mathrm{O}$ ). This selection was based on their relevance for the Paracoccidioides metabolism. For each ICL binding protein, we generated two models of interaction featuring the two most stable conformations of the complex. Through the P. lutzii ICL docking analysis and the contact preference regions analysis, 30 complexes have been proposed (Figure 7). 

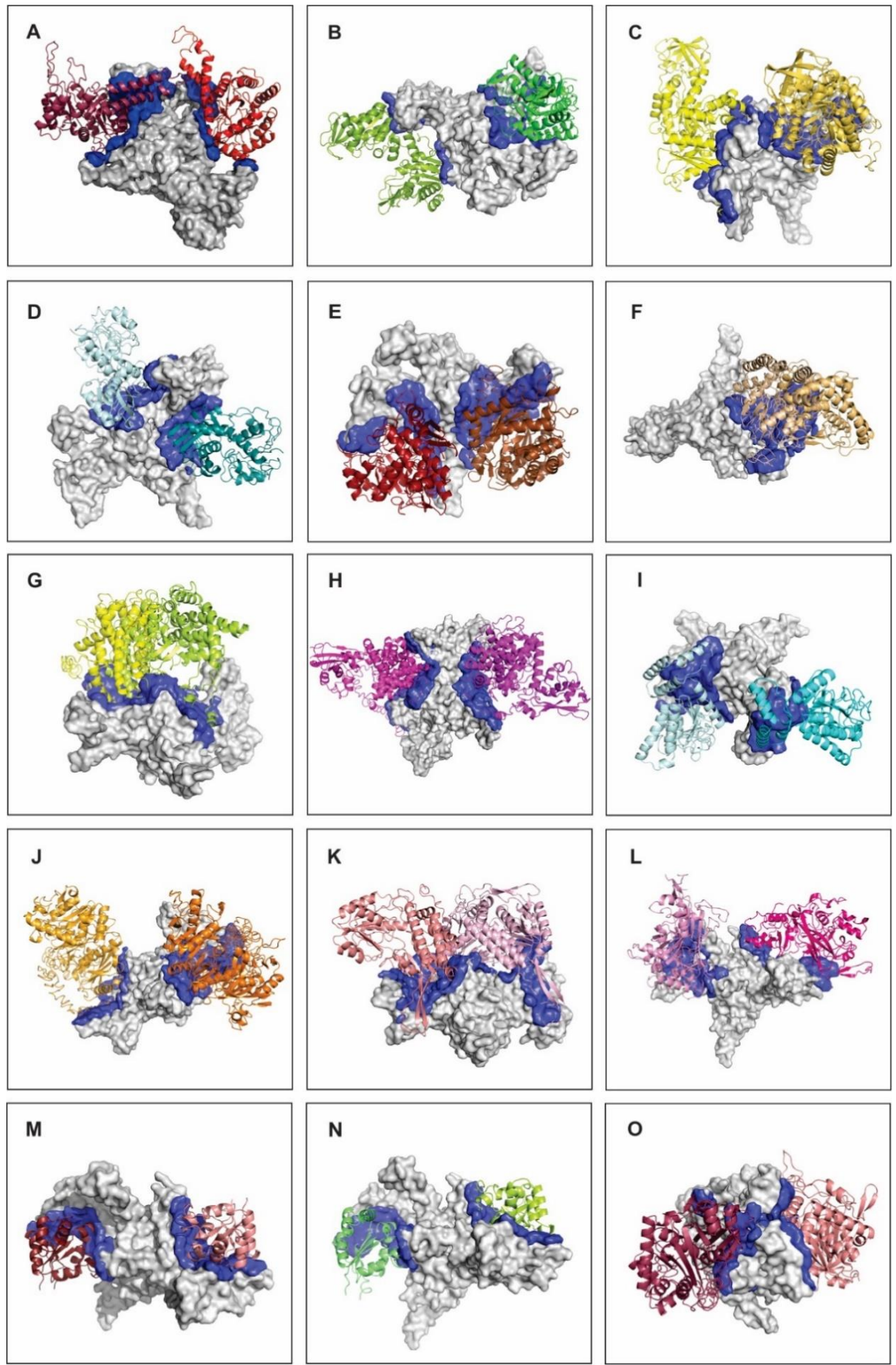

Figure 6. Schematic representation of $P$. lutzii ICL interactions with 15 metabolic protein partners. Each image shows two conformations of P. lutzii ICL (gray), its protein partners (different colors) and the interacting interface (dark-blue). We chose the best two conformations of the complexes with the lowest free energy in order to represent the most probable regions of ICL interaction with other proteins. (A) fructose-bisphosphate aldolase (FBA1); (B) phosphoglycerate kinase; (C) pyruvate kinase; (D) glyceraldehyde-3-phosphate dehydrogenase; (E) enolase; (F) malate dehydrogenase; (G) 2-methylcitrate synthase; (H) 2-methylcitrate dehydratase; (I) enoyl-CoA-hydratase (ECH); (J) phosphoenolpyruvate carboxykinase; (K) alcohol dehydrogenase (ADH); (L) fumarylacetoacetase (FAA); (M) ribose-phosphate pyrophosphokinase (RPP); (N) nucleoside diphosphate kinase (NDK); (O) acetyl-CoA acetyltransferase (ACA). (A-D,F-H,J) interacted with ICL in $P$. lutzii protein extracts in the chromatographic assay and $(\mathbf{E}, \mathbf{I}, \mathbf{K}-\mathbf{O})$ interacted with ICL in P. lutzii protein extracts in the BN-PAGE assay. 


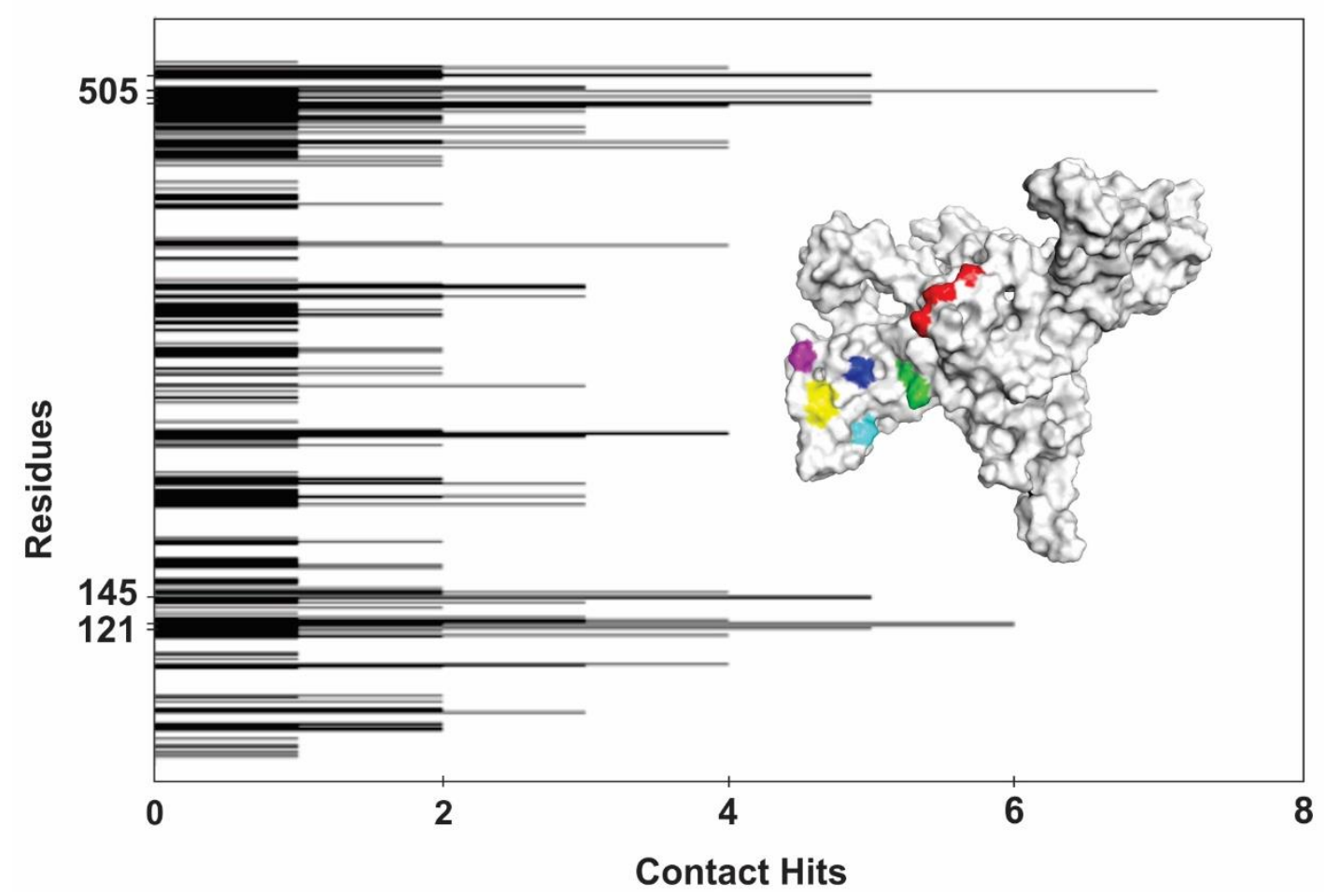

Figure 7. Contact preference residues of $P$. lutzii ICL interacting with metabolic proteins. The contact preference analysis showed the frequency of interaction between ICL amino acid residues and its selected metabolic protein partners. ICL region around residue 505 is the most energetically favored to interact with amino acids from ICL-binding proteins with 5-7 hits of interaction and region around residue 121 with 5-6 hits. The three-dimensional structure shown here highlights the seven residues that interact with ICL partners most frequently. The colors represent the amino acids scored as hot spots, MET 120 and ASN 121 (red), GLN 502 and LYS 503 (green), SER 505 (dark blue), LYS 513 (pink), SER 525 and ARG 526 (yellow) and VAL 530 (light blue).

We found seven ICL regions that interacted with the selected protein partners. Figure 7 highlights the seven main regions that participate in the P. lutzii ICL interactions. The small colored areas are regions with residues that most frequently interact with the 15 selected proteins for this in silico analysis. Figure 6 highlights the interface of interaction between ICL and its binding proteins, those contact amino acids are spread around that interface region. All ICL partners interacted with SER 505, which seems to be the most important hot spot that energetically contributes to the stabilization of the binary complex conformation. MET 120 and ASN 121 are contact residues between ICL and FBA1, PGK, PK, GAPDH and ENO. The fact that those proteins belong to the glycolytic pathway and since they share similar contact residues with ICL, reinforce the idea of the existence of a glycolytic metabolon in P. lutzii [84]. GLN 502 and LYS 503 establish contact between ICL and partners in ENO, MDH, MCS and MCD, while LYS 513 of ICL interacts with PK, MDH, ECH and ACA. The residues SER 525 and ARG 526 are present in the interface of interaction binding to FBA1, PEPCK, ADH, NDK and ACA. Finally, the residue VAL 530 interacts with PGK, MCS, ADH, FAA and RPP.

\subsection{The Amino Acid Residue 505 of ICL Belongs to a Very Active Binding Region}

The availability of big data post-high-throughput era provides means to predict networks of PPIs. An interesting approach regarding contact preference regions categorized PPI complexes available in Swissprot and PDB showed that certain amino acids are preferred for specific types of interfaces [85]. Hydrophobic interactions are the most important forces within the contact preference regions [86] and the most frequent residues that interacted with ICL partners were hydrophobic. 
The graphic in Figure 7 represents the contact preference regions of $P$. lutzii ICL and its protein partners. The graphic points out that the ICL binding region near residue 505 is the region with the most preferable area of interaction. The area near residues 120, 121, 145, 502, 503 and 529 are also very active and most of the protein partners of $P$. lutzii ICL interact with residues on these contact preference regions.

\section{Concluding Remarks}

We performed three different assays of PPIs in order to establish the protein partners of ICL. ICL may interfere with central metabolism of P. lutzii, regulating aerobic and anaerobic metabolism in mycelium, mycelium-to-yeast transition and yeast cells as it interacts with proteins from glycolysis, gluconeogenesis, TCA and methylcitrate cycles. The data presented here demonstrate that the function of ICL extends beyond lipid metabolism and that this protein has a role in regulating anaplerotic reactions of central metabolism. ICL has seven regions that interacted with the selected protein partners more frequently. The residue 505 is the region with the most preferable area of interaction.

\section{Future Perspective}

The PCM treatment presents limitations, such as administration of toxic antifungals for an extended period. The search for new potential antifungals is extremely relevant. Studies on PPIs have led to the findings of new antifungal compounds and the design of promising small molecules (peptides) also with antifungal properties. This is the future perspective of the innovative study presented here. In this work, we describe the PPI profile of P. lutzii ICL with metabolic proteins. The results presented here will provide ways of screening new ICL inhibiting compounds and the design of ICL modulator peptides to be tested as anti-PCM. ICL is a good target for PCM new therapies, because this enzyme is absent in humans and has been described as an important virulence factor to several pathogens.

Supplementary Materials: The following are available online at http://www.mdpi.com/2309-608X/6/4/309/s1, Figure S1, ICL interacting proteins according to STRING database. STRING database identified 31 P. lutzii ICL partners. The cut-off score selected was less stringent $(0.6)$ in order to verify if the number of PPIs from the STRING database that corroborates our lab-bench result increases. Table S1, Crystal structures and scores of the ICL interacting proteins modeled by the I-TASSER server.

Author Contributions: Conceptualization, M.P.; data curation, K.S.F.eS., R.M.L., P.d.S.L. and L.C.B.; formal analysis, R.A.d.S. and M.P.; funding acquisition, M.P. and C.M.d.A.S.; investigation, K.S.F.eS., P.d.S.L. and M.P.; methodology, K.S.F.eS. and M.P.; project administration, C.M.d.A.S. and M.P.; supervision, M.P.; writing-original draft, K.S.F.eS.; writing - review and editing, M.P. All authors have read and agreed to the published version of the manuscript.

Funding: This work performed at Universidade Federal de Goiás was supported by MCTI/CNPq (Ministério da Ciência e Tecnologia/Conselho Nacional de Desenvolvimento Científico e Tecnológico), FNDCT (Fundo Nacional de Desenvolvimento Científico e Tecnológico), FAPEG (Fundação de Amparo à Pesquisa do Estado de Goiás), CAPES (Coordenação de Aperfeiçoamento de Pessoal de Nivel Superior), FINEP (Financiadora de Estudos e Projetos), INCT-IF (Instituto Nacional de Ciência e Tecnologia para Inovação Farmacêutica) and PRONEX (Programa de Apoio a Núcleos de Excelência). Additionally, KSFS and RML were supported by fellowship from CAPES. The authors have no other relevant affiliations or financial involvement with any organization or entity with a financial interest in or financial conflict with the subject matter or materials discussed in the manuscript apart from those disclosed.

Conflicts of Interest: The authors declare no conflict of interest.

\section{References}

1. Muñoz, J.F.; Farrer, R.A.; Desjardins, C.A.; Gallo, J.E.; Sykes, S.; Sakthikumar, S.; Misas, E.; Whiston, E.A.; Bagagli, E.; Soares, C.M.A.; et al. Genome Diversity, Recombination, and Virulence across the Major Lineages of Paracoccidioides. mSphere 2016, 1, e00213-16. [CrossRef] [PubMed]

2. Turissini, D.A.; Gomez, O.M.; Teixeira, M.M.; McEwen, J.G.; Matute, D.R. Species boundaries in the human pathogen Paracoccidioides. Fungal Genet. Biol. 2017, 106, 9-25. [CrossRef] [PubMed] 
3. Brummer, E.; Castaneda, E.; Restrepo, A. Paracoccidioidomycosis: An update. Clin. Microbiol. Rev. 1993, 6, 89-117. [PubMed]

4. Franco, M.; Peracoli, M.T.; Soares, A.; Montenegro, R.; Mendes, R.P.; Meira, D.A. Host-parasite relationship in paracoccidioidomycosis. Curr. Top. Med. Mycol. 1993, 5, 115-149. [PubMed]

5. Felipe, M.S.S.; Andrade, R.V.; Arraes, F.B.M.; Nicola, A.M.; Maranhão, A.Q.; Torres, F.A.G.; Silva-Pereira, I.; Poças-Fonseca, M.J.; Campos, E.G.; Moraes, L.M.P.; et al. Transcriptional profiles of the human pathogenic fungus Paracoccidioides brasiliensis in mycelium and yeast cells. J. Biol. Chem. 2005, 280, 24706-24714. [CrossRef]

6. Rezende, T.C.V.; Borges, C.L.; Magalhães, A.D.; de Sousa, M.V.; Ricart, C.A.O.; Bailão, A.M.; Soares, C.M.A. A quantitative view of the morphological phases of Paracoccidioides brasiliensis using proteomics. J. Proteom. 2011, 75, 572-587. [CrossRef]

7. Camacho, E.; Niño-Vega, G.A. Paracoccidioides Spp.: Virulence Factors and Immune-Evasion Strategies. Mediat. Inflamm. 2017, 2017, 5313691. [CrossRef]

8. de Macedo, P.M.; Almeida-Paes, R.; de Almeida, M.A.; Coelho, R.A.; Andrade, H.B.; Ferreira, A.B.T.B.C.; Zancopé-Oliveira, R.M.; Valle, A.C.F. Paracoccidioidomycosis due to Paracoccidioides brasiliensis S1 plus HIV co-infection. Mem. Inst. Oswaldo Cruz 2018, 113, 167-172. [CrossRef]

9. Zhai, B.; Lin, X. Recent progress on antifungal drug development. Curr. Pharm. Biotechnol. 2011, 12, $1255-1262$.

10. Araújo, F.S.; Coelho, L.M.; Silva, L.d.C.; Neto, B.R.d.S.; Parente-Rocha, J.A.; Bailão, A.M.; de Oliveira, C.M.A.; Fernandes, G.d.R.; Hernández, O.; Ochoa, J.G.M.; et al. Effects of Argentilactone on the Transcriptional Profile, Cell Wall and Oxidative Stress of Paracoccidioides spp. PLoS Negl. Trop. Dis. 2016, 10, e0004309. [CrossRef]

11. Prado, R.S.d.; Alves, R.J.; de Oliveira, C.M.A.; Kato, L.; Silva, R.A.d.; Quintino, G.O.; Cunha, S.d.D.; Soares, C.M.d.A.; Pereira, M. Inhibition of Paracoccidioides lutzii Pb01 Isocitrate Lyase by the Natural Compound Argentilactone and Its Semi-Synthetic Derivatives. PLoS ONE 2014, 9, e94832. [CrossRef]

12. Prado, R.S.; Bailão, A.M.; Silva, L.C.; de Oliveira, C.M.A.; Marques, M.F.; Silva, L.P.; Silveira-Lacerda, E.P.; Lima, A.P.; Soares, C.M.; Pereira, M. Proteomic profile response of Paracoccidioides lutzii to the antifungal argentilactone. Front. Microbiol. 2015, 6, 616. [CrossRef] [PubMed]

13. Zambuzzi-Carvalho, P.F.; Tomazett, P.K.; Santos, S.C.; Ferri, P.H.; Borges, C.L.; Martins, W.S.; de Almeida Soares, C.M.; Pereira, M. Transcriptional profile of Paracoccidioides induced by oenothein B, a potential antifungal agent from the Brazilian Cerrado plant Eugenia uniflora. BMC Microbiol. 2013, 13, 227. [CrossRef]

14. Lorenz, M.C.; Fink, G.R. Life and death in a macrophage: Role of the glyoxylate cycle in virulence. Eukaryot. Cell 2002, 1, 657-662. [PubMed]

15. Cheah, H.-L.; Lim, V.; Sandai, D. Inhibitors of the Glyoxylate Cycle Enzyme ICL1 in Candida albicans for Potential Use as Antifungal Agents. PLoS ONE 2014, 9, e95951. [CrossRef]

16. Lee, H.-S.; Yoon, K.-M.; Han, Y.-R.; Lee, K.J.; Chung, S.-C.; Kim, T.-I.; Lee, S.-H.; Shin, J.; Oh, K.-B. 5-Hydroxyindole-type alkaloids, as Candida albicans isocitrate lyase inhibitors, from the tropical sponge Hyrtios sp. Bioorg. Med. Chem. Lett. 2009, 19, 1051-1053. [CrossRef]

17. Krieger, I.V.; Freundlich, J.S.; Gawandi, V.B.; Roberts, J.P.; Gawandi, V.B.; Sun, Q.; Owen, J.L.; Fraile, M.T.; Huss, S.I.; Lavandera, J.-L.; et al. Structure-guided discovery of phenyl-diketo acids as potent inhibitors of M. tuberculosis malate synthase. Chem. Biol. 2012, 19, 1556-1567. [CrossRef]

18. Lee, Y.-V.; Wahab, H.A.; Choong, Y.S. Potential Inhibitors for Isocitrate Lyase of Mycobacterium Tuberculosis and Non-M. Tuberculosis: A Summary. Available online: https://www.hindawi.com/journals/bmri/2015/ 895453/ (accessed on 25 April 2019).

19. Dunn, M.F.; Ramírez-Trujillo, J.A.; Hernández-Lucas, I. Major roles of isocitrate lyase and malate synthase in bacterial and fungal pathogenesis. Microbiology 2009, 155, 3166-3175. [CrossRef]

20. Nakazawa, M.; Nishimura, M.; Inoue, K.; Ueda, M.; Inui, H.; Nakano, Y.; Miyatake, K. Characterization of a bifunctional glyoxylate cycle enzyme, malate synthase/isocitrate lyase, of Euglena gracilis. J. Eukaryot. Microbiol. 2011, 58, 128-133. [CrossRef]

21. Harrop Linda, C. Kornberg Hans Leo The role of isocitrate lyase in the metabolism of algae. Proc. R. Soc. Lond. Ser. B Biol. Sci. 1966, 166, 11-29. [CrossRef]

22. Pinzauti, G.; Giachetti, E.; Camici, G.; Manao, G.; Cappugi, G.; Vanni, P. An isocitrate lyase of higher plants: Analysis and comparison of some molecular properties. Arch. Biochem. Biophys. 1986, 244, 85-93. [CrossRef] [PubMed] 
23. Muñoz-Elías, E.J.; McKinney, J.D. M. tuberculosis isocitrate lyases 1 and 2 are jointly required for in vivo growth and virulence. Nat. Med. 2005, 11, 638-644. [CrossRef] [PubMed]

24. Cusick, M.E.; Klitgord, N.; Vidal, M.; Hill, D.E. Interactome: Gateway into systems biology. Hum. Mol. Genet. 2005, 14 (Suppl. S2), R171-R181. [CrossRef]

25. Prieto, C.; De Las Rivas, J. Structural domain-domain interactions: Assessment and comparison with protein-protein interaction data to improve the interactome. Proteins 2010, 78, 109-117. [CrossRef] [PubMed]

26. Giardina, B.J.; Stanley, B.A.; Chiang, H.-L. Glucose induces rapid changes in the secretome of Saccharomyces cerevisiae. Proteome Sci. 2014, 12, 9. [CrossRef] [PubMed]

27. Sarry, J.-E.; Chen, S.; Collum, R.P.; Liang, S.; Peng, M.; Lang, A.; Naumann, B.; Dzierszinski, F.; Yuan, C.-X.; Hippler, M.; et al. Analysis of the vacuolar luminal proteome of Saccharomyces cerevisiae. FEBS J. 2007, 274, 4287-4305. [CrossRef] [PubMed]

28. Taylor, K.M.; Kaplan, C.P.; Gao, X.; Baker, A. Localization and targeting of isocitrate lyases in Saccharomyces cerevisiae. Biochem. J. 1996, 319 Pt 1, 255-262. [CrossRef]

29. Chaves, R.S.; Herrero, P.; Ordiz, I.; Angeles del Brio, M.; Moreno, F. Isocitrate lyase localisation in Saccharomyces cerevisiae cells. Gene 1997, 198, 165-169. [CrossRef]

30. Fava-Netto, C.; Raphael, A.A. Reação intradérmica com polissacarídeo do Paracaccidioides brasiliensis, na blastomicose sul-americana. Rev. Inst. Med. Trop. 1961, 4, 161-165.

31. Cruz, A.H.d.S.; Brock, M.; Zambuzzi-Carvalho, P.F.; Santos-Silva, L.K.; Troian, R.F.; Góes, A.M.; Soares, C.M.d.A.; Pereira, M. Phosphorylation is the major mechanism regulating isocitrate lyase activity in Paracoccidioides brasiliensis yeast cells. FEBS J. 2011, 278, 2318-2332. [CrossRef]

32. Barbosa, H.; Slater, N.K.H.; Marcos, J.C. Protein quantification in the presence of poly(ethylene glycol) and dextran using the Bradford method. Anal. Biochem. 2009, 395, 108-110. [CrossRef] [PubMed]

33. Schägger, H.; Cramer, W.A.; von Jagow, G. Analysis of molecular masses and oligomeric states of protein complexes by blue native electrophoresis and isolation of membrane protein complexes by two-dimensional native electrophoresis. Anal. Biochem. 1994, 217, 220-230. [PubMed]

34. Gilar, M.; Olivova, P.; Daly, A.E.; Gebler, J.C. Two-dimensional separation of peptides using RP-RP-HPLC system with different $\mathrm{pH}$ in first and second separation dimensions. J. Sep. Sci. 2005, 28, 1694-1703. [PubMed]

35. Geromanos, S.J.; Vissers, J.P.C.; Silva, J.C.; Dorschel, C.A.; Li, G.-Z.; Gorenstein, M.V.; Bateman, R.H.; Langridge, J.I. The detection, correlation, and comparison of peptide precursor and product ions from data independent LC-MS with data dependant LC-MS/MS. Proteomics 2009, 9, 1683-1695. [CrossRef]

36. Li, G.-Z.; Vissers, J.P.C.; Silva, J.C.; Golick, D.; Gorenstein, M.V.; Geromanos, S.J. Database searching and accounting of multiplexed precursor and product ion spectra from the data independent analysis of simple and complex peptide mixtures. Proteomics 2009, 9, 1696-1719. [CrossRef]

37. Murad, A.M.; Souza, G.H.M.F.; Garcia, J.S.; Rech, E.L. Detection and expression analysis of recombinant proteins in plant-derived complex mixtures using nanoUPLC-MSE. J. Sep. Sci. 2011, 34, 2618-2630. [CrossRef]

38. Araiza-Olivera, D.; Chiquete-Felix, N.; Rosas-Lemus, M.; Sampedro, J.G.; Peña, A.; Mujica, A.; Uribe-Carvajal, S. A glycolytic metabolon in Saccharomyces cerevisiae is stabilized by F-actin. FEBS J. 2013, 280, 3887-3905. [CrossRef]

39. Szklarczyk, D.; Franceschini, A.; Kuhn, M.; Simonovic, M.; Roth, A.; Minguez, P.; Doerks, T.; Stark, M.; Muller, J.; Bork, P.; et al. The STRING database in 2011: Functional interaction networks of proteins, globally integrated and scored. Nucleic Acids Res. 2011, 39, D561-D568. [CrossRef]

40. Yang, J.; Yan, R.; Roy, A.; Xu, D.; Poisson, J.; Zhang, Y. The I-TASSER Suite: Protein structure and function prediction. Nat. Methods 2015, 12, 7-8. [CrossRef]

41. Chen, V.B.; Arendall, W.B.; Headd, J.J.; Keedy, D.A.; Immormino, R.M.; Kapral, G.J.; Murray, L.W.; Richardson, J.S.; Richardson, D.C. MolProbity: All-atom structure validation for macromolecular crystallography. Acta Cryst. D Biol. Cryst. 2010, 66, 12-21. [CrossRef]

42. da Silva, L.S.; Barbosa, U.R.; Silva, L.d.C.; Soares, C.M.; Pereira, M.; da Silva, R.A. Identification of a new antifungal compound against isocitrate lyase of Paracoccidioides brasiliensis. Future Microbiol. 2019, 14, 1589-1606. [CrossRef] [PubMed]

43. Okimoto, N.; Futatsugi, N.; Fuji, H.; Suenaga, A.; Morimoto, G.; Yanai, R.; Ohno, Y.; Narumi, T.; Taiji, M. High-performance drug discovery: Computational screening by combining docking and molecular dynamics simulations. PLoS Comput. Biol. 2009, 5, e1000528. [CrossRef] 
44. Daura, X.; Gademann, K.; Jaun, B.; Seebach, D.; van Gunsteren, W.F.; Mark, A.E. Peptide Folding: When Simulation Meets Experiment. Angew. Chem. Int. Ed. 1999, 38, 236-240. [CrossRef]

45. Pronk, S.; Páll, S.; Schulz, R.; Larsson, P.; Bjelkmar, P.; Apostolov, R.; Shirts, M.R.; Smith, J.C.; Kasson, P.M.; van der Spoel, D.; et al. GROMACS 4.5: A high-throughput and highly parallel open source molecular simulation toolkit. Bioinformatics 2013, 29, 845-854. [CrossRef] [PubMed]

46. Tovchigrechko, A.; Vakser, I.A. GRAMM-X public web server for protein-protein docking. Nucleic Acids Res. 2006, 34, W310-W314. [CrossRef]

47. Zhu, X.; Mitchell, J.C. KFC2: A knowledge-based hot spot prediction method based on interface solvation, atomic density, and plasticity features. Proteins 2011, 79, 2671-2683. [CrossRef]

48. Vangone, A.; Spinelli, R.; Scarano, V.; Cavallo, L.; Oliva, R. COCOMAPS: A web application to analyze and visualize contacts at the interface of biomolecular complexes. Bioinformatics 2011, 27, 2915-2916. [CrossRef]

49. Santos, L.P.A.; Assunção, L.d.P.; Lima, P.d.S.; Tristão, G.B.; Brock, M.; Borges, C.L.; Silva-Bailão, M.G.; Soares, C.M.d.A.; Bailão, A.M. Propionate metabolism in a human pathogenic fungus: Proteomic and biochemical analyses. IMA Fungus 2020, 11, 9. [CrossRef]

50. Barbosa, M.S.; Báo, S.N.; Andreotti, P.F.; de Faria, F.P.; Felipe, M.S.S.; dos Santos Feitosa, L.; Mendes-Giannini, M.J.S.; de Almeida Soares, C.M. Glyceraldehyde-3-phosphate dehydrogenase of Paracoccidioides brasiliensis is a cell surface protein involved in fungal adhesion to extracellular matrix proteins and interaction with cells. Infect. Immun. 2006, 74, 382-389. [CrossRef]

51. Nogueira, S.V.; Fonseca, F.L.; Rodrigues, M.L.; Mundodi, V.; Abi-Chacra, E.A.; Winters, M.S.; Alderete, J.F.; de Almeida Soares, C.M. Paracoccidioides brasiliensis enolase is a surface protein that binds plasminogen and mediates interaction of yeast forms with host cells. Infect. Immun. 2010, 78, 4040-4050. [CrossRef]

52. Pereira, L.A.; Báo, S.N.; Barbosa, M.S.; Silva, J.L.M.D.; Felipe, M.S.S.; Santana, J.M.D.; Mendes-Giannini, M.J.S.; Soares, C.M.D.A. Analysis of the Paracoccidioides brasiliensis triosephosphate isomerase suggests the potential for adhesin function. FEMS Yeast Res. 2007, 7, 1381-1388. [CrossRef] [PubMed]

53. Shi, L.; Tu, B.P. Acetyl-CoA and the Regulation of Metabolism: Mechanisms and Consequences. Curr. Opin. Cell Biol. 2015, 33, 125-131. [CrossRef] [PubMed]

54. Plancke, C.; Vigeolas, H.; Höhner, R.; Roberty, S.; Emonds-Alt, B.; Larosa, V.; Willamme, R.; Duby, F.; Onga Dhali, D.; Thonart, P.; et al. Lack of isocitrate lyase in Chlamydomonas leads to changes in carbon metabolism and in the response to oxidative stress under mixotrophic growth. Plant J. 2014, 77, 404-417. [CrossRef] [PubMed]

55. Billones, J.B.; Carrillo, M.C.O.; Organo, V.G.; Macalino, S.J.Y.; Sy, J.B.A.; Emnacen, I.A.; Clavio, N.A.B.; Concepcion, G.P. Toward antituberculosis drugs: In silico screening of synthetic compounds against Mycobacterium tuberculosis 1,d-transpeptidase 2. Drug Des. Dev. Ther. 2016, 10, 1147-1157. [CrossRef]

56. Britton, K.; Langridge, S.; Baker, P.J.; Weeradechapon, K.; Sedelnikova, S.E.; De Lucas, J.R.; Rice, D.W.; Turner, G. The crystal structure and active site location of isocitrate lyase from the fungus Aspergillus nidulans. Structure 2000, 8, 349-362. [PubMed]

57. Aragues, R.; Sali, A.; Bonet, J.; Marti-Renom, M.A.; Oliva, B. Characterization of Protein Hubs by Inferring Interacting Motifs from Protein Interactions. PLoS Comput. Biol. 2007, 3, e178. [CrossRef]

58. Reinscheid, D.J.; Eikmanns, B.J.; Sahm, H. Characterization of the isocitrate lyase gene from Corynebacterium glutamicum and biochemical analysis of the enzyme. J. Bacteriol. 1994, 176, 3474-3483.

59. Ni, D.; Lu, S.; Zhang, J. Emerging roles of allosteric modulators in the regulation of protein-protein interactions (PPIs): A new paradigm for PPI drug discovery. Med. Res. Rev. 2019, 39, 2314-2342. [CrossRef]

60. Blázquez, M.A.; Gamo, F.J.; Gancedo, C. A mutation affecting carbon catabolite repression suppresses growth defects in pyruvate carboxylase mutants from Saccharomyces cerevisiae. FEBS Lett. 1995, 377, 197-200.

61. Jardón, R.; Gancedo, C.; Flores, C.-L. The gluconeogenic enzyme fructose-1,6-bisphosphatase is dispensable for growth of the yeast Yarrowia lipolytica in gluconeogenic substrates. Eukaryot. Cell 2008, 7,1742-1749. [CrossRef]

62. Giardina, B.J.; Chiang, H.-L. Fructose-1,6-bisphosphatase, Malate Dehydrogenase, Isocitrate Lyase, Phosphoenolpyruvate Carboxykinase, Glyceraldehyde-3-phosphate Dehydrogenase, and Cyclophilin A are secreted in Saccharomyces cerevisiae grown in low glucose. Commun. Integr. Biol. 2013, 6, e27216. [CrossRef] [PubMed]

63. Marrero, J.; Rhee, K.Y.; Schnappinger, D.; Pethe, K.; Ehrt, S. Gluconeogenic carbon flow of tricarboxylic acid cycle intermediates is critical for Mycobacterium tuberculosis to establish and maintain infection. Proc. Natl. Acad. Sci. USA 2010, 107, 9819-9824. [CrossRef] [PubMed] 
64. Beste, D.J.V.; Bonde, B.; Hawkins, N.; Ward, J.L.; Beale, M.H.; Noack, S.; Nöh, K.; Kruger, N.J.; Ratcliffe, R.G.; McFadden, J. ${ }^{13} \mathrm{C}$ metabolic flux analysis identifies an unusual route for pyruvate dissimilation in mycobacteria which requires isocitrate lyase and carbon dioxide fixation. PLoS Pathog. 2011, 7, e1002091. [CrossRef]

65. Rylott, E.L.; Gilday, A.D.; Graham, I.A. The Gluconeogenic Enzyme Phosphoenolpyruvate Carboxykinase in Arabidopsis Is Essential for Seedling Establishment. Plant Physiol. 2003, 131, 1834-1842. [CrossRef]

66. Chen, Z.-H.; Walker, R.P.; Acheson, R.M.; Técsi, L.I.; Wingler, A.; Lea, P.J.; Leegood, R.C. Are Isocitrate Lyase and Phosphoenolpyruvate Carboxykinase Involved in Gluconeogenesis during Senescence of Barley Leaves and Cucumber Cotyledons? Plant Cell Physiol. 2000, 41, 960-967. [CrossRef]

67. Gengenbacher, M.; Rao, S.P.S.; Pethe, K.; Dick, T. Nutrient-starved, non-replicating Mycobacterium tuberculosis requires respiration, ATP synthase and isocitrate lyase for maintenance of ATP homeostasis and viability. Microbiology 2010, 156, 81-87. [CrossRef]

68. Williams, N.C.; O'Neill, L.A.J. A Role for the Krebs Cycle Intermediate Citrate in Metabolic Reprogramming in Innate Immunity and Inflammation. Front. Immunol. 2018, 9. [CrossRef]

69. Eoh, H.; Rhee, K.Y. Methylcitrate cycle defines the bactericidal essentiality of isocitrate lyase for survival of Mycobacterium tuberculosis on fatty acids. Proc. Natl. Acad. Sci. USA 2014, 111, 4976-4981. [CrossRef]

70. Meijer, S.; Otero, J.; Olivares, R.; Andersen, M.R.; Olsson, L.; Nielsen, J. Overexpression of isocitrate lyase-glyoxylate bypass influence on metabolism in Aspergillus niger. Metab. Eng. 2009, 11, 107-116.

71. Kanamasa, S.; Tajima, S.; Park, E.Y. Isocitrate dehydrogenase and isocitrate lyase are essential enzymes for riboflavin production in Ashbya gossypii. Biotechnol. Bioprocess Eng. 2007, 12, 92. [CrossRef]

72. Liu, F.; Thatcher, J.D.; Barral, J.M.; Epstein, H.F. Bifunctional glyoxylate cycle protein of Caenorhabditis elegans: A developmentally regulated protein of intestine and muscle. Dev. Biol. 1995, 169, 399-414. [CrossRef] [PubMed]

73. Nakazawa, M.; Minami, T.; Teramura, K.; Kumamoto, S.; Hanato, S.; Takenaka, S.; Ueda, M.; Inui, H.; Nakano, Y.; Miyatake, K. Molecular characterization of a bifunctional glyoxylate cycle enzyme, malate synthase/isocitrate lyase, in Euglena gracilis. Comp. Biochem. Physiol. B Biochem. Mol. Biol. 2005, 141, 445-452. [CrossRef] [PubMed]

74. Sweetlove, L.J.; Fernie, A.R. The role of dynamic enzyme assemblies and substrate channelling in metabolic regulation. Nat. Commun. 2018, 9, 2136. [CrossRef] [PubMed]

75. Arikawa, Y.; Enomoto, K.; Muratsubaki, H.; Okazaki, M. Soluble fumarate reductase isoenzymes from Saccharomyces cerevisiae are required for anaerobic growth. FEMS Microbiol. Lett. 1998, 165, 111-116. [CrossRef] [PubMed]

76. Raab, A.M.; Gebhardt, G.; Bolotina, N.; Weuster-Botz, D.; Lang, C. Metabolic engineering of Saccharomyces cerevisiae for the biotechnological production of succinic acid. Metab. Eng. 2010, 12, 518-525. [CrossRef] [PubMed]

77. Rezaei, M.N.; Aslankoohi, E.; Verstrepen, K.J.; Courtin, C.M. Contribution of the tricarboxylic acid (TCA) cycle and the glyoxylate shunt in Saccharomyces cerevisiae to succinic acid production during dough fermentation. Int. J. Food Microbiol. 2015, 204, 24-32. [CrossRef] [PubMed]

78. Jayashree, S.; Murugavel, P.; Sowdhamini, R.; Srinivasan, N. Interface residues of transient protein-protein complexes have extensive intra-protein interactions apart from inter-protein interactions. Biol. Direct 2019, 14, 1. [CrossRef]

79. Gurung, A.B.; Bhattacharjee, A.; Ajmal Ali, M.; Al-Hemaid, F.; Lee, J. Binding of small molecules at interface of protein-protein complex-A newer approach to rational drug design. Saudi J. Biol. Sci. 2017, 24, 379-388. [CrossRef]

80. Talavera, D.; Robertson, D.L.; Lovell, S.C. Characterization of Protein-Protein Interaction Interfaces from a Single Species. PLoS ONE 2011, 6, e21053. [CrossRef]

81. Zybailov, B.; Gokulan, K.; Wiese, J.; Ramanagoudr-Bhojappa, R.; Byrd, A.K.; Glazko, G.; Jaiswal, M.; Mackintosh, S.; Varughese, K.I.; Raney, K.D. Analysis of Protein-protein Interaction Interface between Yeast Mitochondrial Proteins Rim1 and Pif1 Using Chemical Cross-linking Mass Spectrometry. J. Proteom. Bioinform. 2015, 8, 243-252. [CrossRef]

82. Swapna, L.S.; Bhaskara, R.M.; Sharma, J.; Srinivasan, N. Roles of residues in the interface of transient protein-protein complexes before complexation. Sci. Rep. 2012, 2. [CrossRef] 
83. Ho, O.; Rogne, P.; Edgren, T.; Wolf-Watz, H.; Login, F.H.; Wolf-Watz, M. Characterization of the Ruler Protein Interaction Interface on the Substrate Specificity Switch Protein in the Yersinia Type III Secretion System. J. Biol. Chem. 2017, 292, 3299-3311. [CrossRef] [PubMed]

84. E Silva, K.S.F.; Lima, R.M.; Baeza, L.C.; Lima, P.d.S.; Cordeiro, T.d.M.; Charneau, S.; da Silva, R.A.; Soares, C.M.d.A.; Pereira, M. Interactome of Glyceraldehyde-3-Phosphate Dehydrogenase Points to the Existence of Metabolons in Paracoccidioides lutzii. Front. Microbiol. 2019, 10, 1537. [CrossRef] [PubMed]

85. Ofran, Y.; Rost, B. Analysing six types of protein-protein interfaces. J. Mol. Biol. 2003, 325, 377-387. [PubMed]

86. Glaser, F.; Steinberg, D.M.; Vakser, I.A.; Ben-Tal, N. Residue frequencies and pairing preferences at protein-protein interfaces. Proteins 2001, 43, 89-102.

Publisher's Note: MDPI stays neutral with regard to jurisdictional claims in published maps and institutional affiliations.

(C) 2020 by the authors. Licensee MDPI, Basel, Switzerland. This article is an open access article distributed under the terms and conditions of the Creative Commons Attribution (CC BY) license (http://creativecommons.org/licenses/by/4.0/). 